\title{
The Kennack Gneiss of the Lizard Peninsula, Cornwall, SW England: commingling and mixing of mafic and felsic magmas accompanying Givetian continental incorporation of the Lizard ophiolite
}

\author{
HAMISH A. I. SANDEMAN ${ }^{1}$, ALAN H. CLARK ${ }^{2}$, DAVID J. SCOTT ${ }^{1,4} \&$ JOHN G. MALPAS ${ }^{3}$ \\ ${ }^{1}$ Geological Survey of Canada, 601 Booth St., Ottawa, Ontario, Canada K1A 0E8 (E-mail: hsandema@nrcan.gc.ca) \\ ${ }^{2}$ Department of Geological Sciences and Geological Engineering, Queen's University, Kingston, Ontario, \\ Canada K7L $3 N 6$ \\ ${ }^{3}$ Department of Earth Sciences, Hong Kong University, Pokfulham Road, Hong Kong, \\ People's Republic of China \\ ${ }^{4}$ Present address: Canada-Nunavut Geoscience Office, Building 1306, PO Box 2319, Iqualuit, Nunavut, \\ Canada XOA $0 H O$
}

\begin{abstract}
The Kennack Gneiss comprises a suite of interlayered mafic and felsic igneous rocks that intruded the $397 \mathrm{Ma}$ Lizard Ophiolite Complex, Cornwall, at $376.4 \pm 1.7 \mathrm{Ma}$ (U-Pb single-zircon date) and were shortly thereafter (c. $370 \mathrm{Ma}$ ) metamorphosed to the amphibolite facies. Weakly deformed examples at the type-locality of Kennack Sands reveal net-veining of the mafic by the felsic component, dispersed enclaves of the former in the latter and flame-like interfingering of the two, features indicative of magmatic commingling and mixing.

The silicic components of the Kennack Gneiss range from granodiorite to syenogranite and from metaluminous to peraluminous, the least silicic rocks being the most peraluminous. They were generated through anatexis of a predominantly metasedimentary crustal source having trace element and isotopic compositions comparable to those of the Devonian Gramscatho Group of South Cornwall. The mafic component of the gneiss includes members (group 1) which are weakly enriched in light REE, have minor negative $\mathrm{Ta}, \mathrm{Nb}, \mathrm{P}$ and $\mathrm{Ti}$ anomalies in extended trace element plots, and display primitive, time-corrected ${ }^{143} \mathrm{Nd} /{ }^{144} \mathrm{Nd}$ and ${ }^{87} \mathrm{Sr} /{ }^{86} \mathrm{Sr}$ values, and others (group 2) which are more strongly enriched in all incompatible trace elements, exhibit more prominent negative $\mathrm{Ta}, \mathrm{Nb}, \mathrm{P}$ and $\mathrm{Ti}$ anomalies, and have isotopic ratios intermediate between group 1 mafic components and the associated felsic gneiss. Group 2 represents mixtures of group 1 and granitic melts, whereas group 1 rocks are comparable to EMORB and were probably generated through partial melting of a weakly enriched mantle source. Emplacement of two commingled magmas into the base of the Lizard ophiolite, one representing the products of crustal anatexis, implies that the ophiolite was removed from its oceanic setting and was in the process of obduction in the Givetian.
\end{abstract}

Keywords: Cornwall England, Lizard complex, Kennack Gneiss, U-Pb, anatexis.

The Lizard Complex of Cornwall, SW England, is widely accepted as a dismembered ophiolite (Thayer 1969; Strong et al. 1975; Kirby 1979a, b; Bromley 1979; Styles \& Kirby 1980), representing oceanic lithosphere that originally separated Armorica to the 'south' and the Avalonian margin of Laurentia to the 'north'. Clark et al. (1998a) recently demonstrated the ophiolite to be Early Devonian ( $\geq 397 \pm 2$ $(2 \sigma) \mathrm{Ma}: \mathrm{U}-\mathrm{Pb}$ zircon) in age, a date significantly older than, but overlapping in error with, the only previous age determination ( $375 \pm 34 \mathrm{Ma}$ : Davies 1984$)$. The assembled ophiolite complex is considered to have been initially overridden by the advancing Normannian High at c. $385 \mathrm{Ma}$ (Clark et al. $1998 b$ ) and ultimately emplaced at low-temperature onto the Devonian flysch basins of southern Cornwall during Hercynian orogenesis (Barnes \& Andrews 1984; Holder \& Leveridge 1986; Leveridge et al. 1990). The complex has traditionally been considered to comprise three distinct structural-lithological domains (Bromley 1979): the Crousa Downs Unit, consisting of the heterogeneously textured Crousa and Trelan Gabbros, the former hosting the roots of a sheeted dyke complex (Porthoustock Dykes); the Goonhilly
Downs Unit, dominated by serpentinized peridotite (Green 1964a), mafic cumulate rocks of the Traboe cumulate sequence (Leake \& Styles 1984) and a suite of pyroxene granulites and mylonitized amphibolites of the Traboe schists (Flett 1946; Gibbons \& Thompson 1991); and a Basal Unit incorporating the strongly deformed, metabasaltic, Landewednack schists and a succession of interleaved metasedimentary and metavolcanic rocks termed the Old Lizard Head Series. A suite of compositionally layered, variably deformed rocks, the Kennack Gneiss, occurs within the peridotite of the Goonhilly Downs Unit and along the thrust contact between the Goonhilly and Basal Units (Fig. 1: Teall 1887; Flett 1946; Green 1964b; Malpas \& Langdon 1987).

Controversy has persisted over the origin of the Kennack Gneiss and related rocks ('microgranites' and 'Black Dykes': Flett 1946) since their recognition by De la Beche (1839). They were initially interpreted to represent Archaean basement (Bonney 1896), but more recently have been ascribed either to anatexis and metamorphic differentiation of the underlying Landewednack and/or Old Lizard Head Series schists during displacement of the Palaeozoic ophiolite 

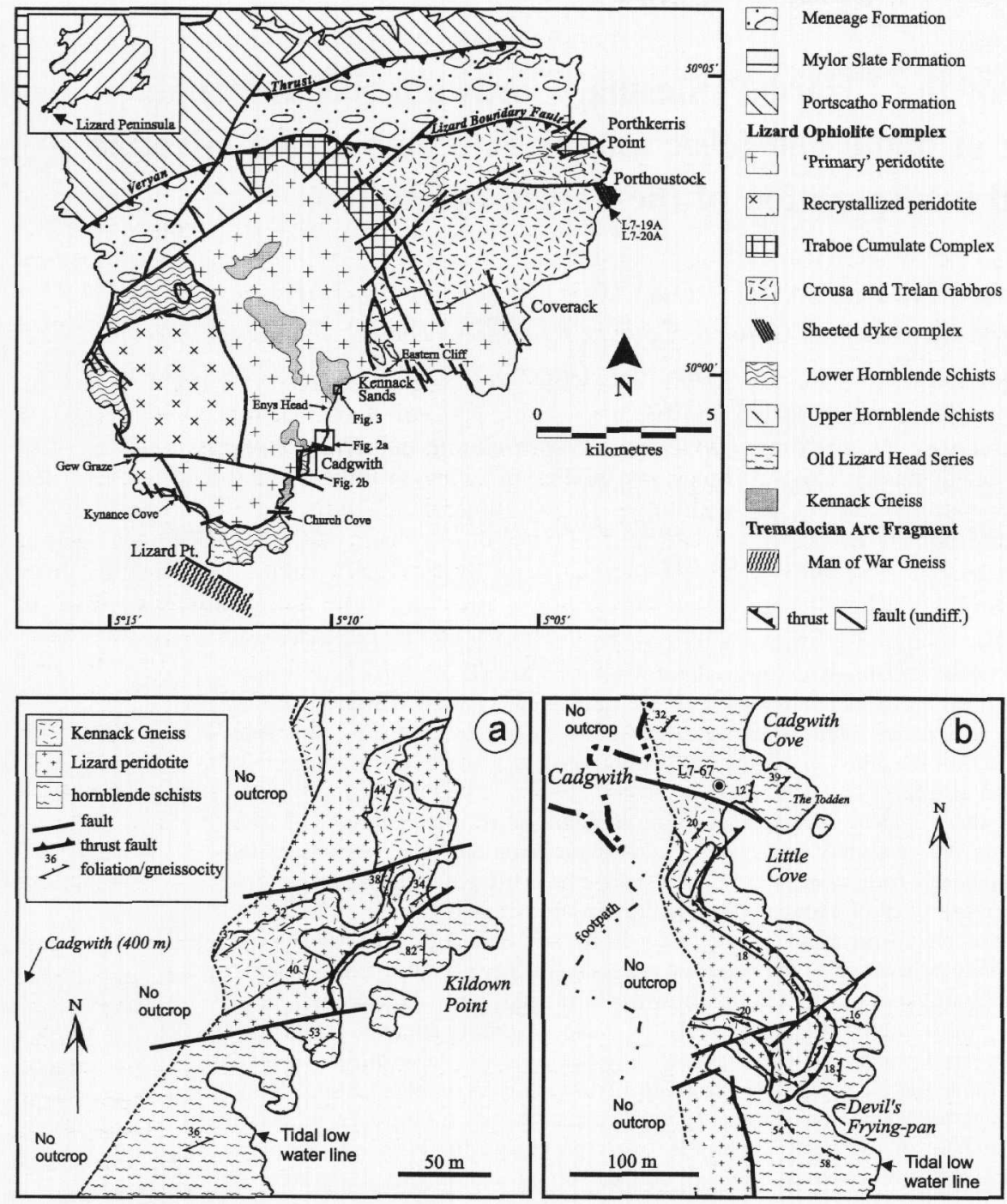

Fig. 1. Geological map of the Lizard Peninsula showing the distribution of rock-types and locations of areas discussed in the text. Also shown are sample locations for ophiolitic dyke specimens L7-19A and L7-20A. Adapted from Floyd et al. (1993) and Leveridge et al. (1990).

Fig. 2. (a) Geological map of the Kildown Point area demonstrating the anastamosing intrusive forms of the Kennack Gneiss and that the gneiss overlies and truncates upright foliation in feldspathic, Traboe-type hornblende schist. (b) Geological map of the area surrounding the Devil's Frying-pan demonstrating the sill-like nature of the Kennack Gneiss at this locality. The location of Landewednack schist sample L7-67 is shown.
(Sanders 1955; Strong et al. 1975; Kirby 1979a; Malpas \& Langdon 1987) or, as first proposed by Teall (1887), to syn-tectonic, coeval intrusion of mafic and felsic magmas into the base of the ophiolite (Flett 1946; Green 1964b; Bromley 1979; Barnes \& Andrews 1986; Sandeman et al. 1995).

We document herein new field and petrographic observations, $\mathrm{U}-\mathrm{Pb}$ geochronological data and chemical and isotopic data for the Kennack Gneiss and associated rocks in order to clarify their age, origin and relationships with the remainder of the ophiolite complex. The gneissose textures are considered to have resulted from progressive deformation of crystallizing and commingling magmas in the course of their emplacement along the basal thrust of the Lizard ophiolite during its continental incorporation. Whole-rock geochemical and radiogenic isotopic data for rocks constrain the nature and petrogenesis of the granitic and basaltic magmas and the extent of their mixing.

\section{Relationships of the Kennack Gneiss to other ophiolitic units}

The intrusive nature of the Kennack Gneiss has been well documented by previous investigators (e.g. Flett 1946; Sanders
1955; Strong et al. 1975; Malpas \& Langdon 1987), but its field relationships with other rock-types of the Lizard Complex are herein summarized to clarify the origin of the gneiss. That the gneiss intruded the Lizard Peridotite is demonstrated by an abundance of dispersed lensoidal xenoliths of the latter and by the consistent parallelism of the layering and mineral foliations in the gneiss bodies with the contacts with the peridotite.

The dominant mafic schists cropping out along the SE coast of the peninsula are fine-grained hornblendeplagioclase \pm epidote metabasites of 'Landewednack-type' (Flett 1946), although metagabbroic, 'Traboe-type', hornblende-plagioclase schist is locally exposed. The relationship between the Kennack Gneiss and the Landewednack schists is clearly seen only at Kildown Point (Figs 1 \& 2a) and on the south side of Cadgwith Cove (Figs 1 \& 2b). At the former locality, a c. $2 \mathrm{~m}$ thick body of banded gneiss is overlain by variably serpentinized peridotite and underlain by grey, feldspathic, hornblende-plagioclase schists. The peridotite is cut by variably trending, irregularly shaped intrusions of banded gneiss exhibiting gneissose and mineral foliations (Fig. 2a) that everywhere parallel the contacts with the peridotite and the metabasites. Therein, the contact between the peridotite and metabasite schists has been interpreted as a thrust fault (Sanders 1955; Kirby 1979a). In the thrust zone 
immediately above the footwall, lenses of felsic Kennack Gneiss directly overlie, and truncate, upright foliation in the footwall Landewednack schists (Fig. 2a), implying that the gneiss was intruded along the thrust fault at this locality.

On the south shore of Cadgwith Cove, a sheet of Kennack Gneiss (Fig. 2b) overlies variably textured hornblendeplagioclase metabasites (Landewednack- and Traboe-type schists), and is itself overlain by peridotite. On the coastal exposures immediately adjacent to the Devil's Frying-pan, the sheet comprises two distinct mafic components: predominant, $\leq 15 \mathrm{~m}$ long, $30 \mathrm{~cm}$ thick layers of a feldspathic, coarsegrained, grey-green amphibolite; and subordinate lenticular slivers ( $\leq 20 \mathrm{~cm}$ long) of fine-grained hornblende-biotiteplagioclase schist. The former are comparable in mineralogy and texture to the underlying hornblende-plagioclase metabasites, and are interpreted as screens incorporated during injection of the gneiss, whereas the latter are similar to the mafic component of the gneiss exposed elsewhere.

Mafic dykes occur sporadically along the southeast coast of the peninsula and typically display NNW-trending orientations comparable to those of the dykes comprising the more northerly Porthoustock swarm (Kirby 1984: Fig. 1). However, they are characterized by amphibolite-grade metamorphic mineral assemblages and typically exhibit a marginparallel foliation, whereas the Porthoustock dykes preserve primary igneous or sub-greenschist mineralogies and are not foliated. Contacts between the Kennack Gneiss and mafic dykes are rarely exposed but, where observed, imply complex interrelationships. At Enys Head (Fig. 1), a 3 m-thick, NWdipping sheet of banded gneiss cuts peridotite, and truncates a $\leq 1 \mathrm{~m}$, vertical, aphanitic mafic dyke at a high-angle. The dyke is in contact with the lower side of the sheet, but is absent above. It is fragmented by a series of small faults paralleling the sheet. Rare small patches ( $\leq 2 \mathrm{~cm}$ in diameter) of felsic component are present, but it is predominantly amphibolitic with the assemblage hornblende+plagioclase, without biotite.

At Eastern Cliff (Fig. 1) peridotite is cut by a weakly sheared mafic dyke, comprising hornblende and plagioclase and containing veinlets of granite paralleling its margins. This can be traced south to the shoreline where it expands into an ovalshaped plug (c. $20 \mathrm{~m}$ across) of predominantly felsic gneiss. The plug is mantled on its northern margin by $\leq 1 \mathrm{~m}$ sheets of mafic gneiss with peridotite inclusions, but its southern margin is not exposed. The presence of the granitic veinlets in the dyke and the close association of the dyke and gneiss body suggest that they are temporally, and possibly petrogenetically, related.

\section{Internal petrological features of the Kennack Gneiss}

The Kennack Gneiss, best exposed along the SE coast of the Lizard Peninsula from Kennack Sands to Church Cove (Fig. 1), also occurs along the west coast and, from the distribution of field rubble, is known to underlie inland areas of the peninsula (Flett 1946; Fig. 1). The gneiss was thought to be restricted in vertical extent, constituting a thin zone proximal to the basal thrust of the Goonhilly Downs unit, but a borehole drilled in 1978 at Kennack Sands by the then Institute of Geological Sciences revealed at least $150 \mathrm{~m}$ of interlayered granitic and mafic rocks interspersed with thin lenses of peridotite (Styles \& Kirby 1980). All field descriptions herein are for coastal exposures, supplemented by petrographic and geochemical data for ten specimens from various depths of the IGS drillcore.

We divide the gneiss into three mutually gradational facies on the basis of the observed proportions and interrelationships of the felsic and mafic constituents: (1) 'felsic gneiss' consisting of at least $70 \%$ of the felsic component; (2) 'banded gneiss' having 30-70\% felsic component; (3) 'mafic gneiss' with less than $30 \%$ of the felsic component. Except along the west coast of the peninsula, the mafic component is predominant, making up $65-70 \%$ of the gneiss in total.

The three facies typically exhibit a gneissose structure, consisting of centimetre-scale bands of mafic and felsic components, all with strong mineral foliations. Locally, nongneissose bodies of either granitic or mafic component also exhibit a strong mineral foliation. Felsic gneiss occurs in greatest abundance in the vicinity of Kennack Sands, characteristically forming bodies with small $(\leq 15 \mathrm{~m}$ in thickness) core-zones of foliated biotite monzogranite enclosed by envelopes of banded gneiss that pass outwards into mafic gneiss and finally into country rock (peridotite). In such examples, a progressive decrease in the proportion of the felsic component is observed towards the margins of the gneiss complex. Variably foliated, fault-bounded bodies of monzogranite, typically lacking mafic interbands, occur along the west coast (Fig. 1) and are considered to be equivalent to the felsic component of the gneiss (Flett 1946). Metasedimentary xenoliths have nowhere been identified in any facies of the gneiss.

Banded gneiss is volumetrically the most abundant and, where accompanied by felsic and mafic gneiss, appears to represent a gradation between the two. The distinction between mafic gneiss lacking a felsic component and other fine-grained mafic rocks of the ophiolite is difficult to make on the basis of field criteria, because most have been metamorphosed to amphibolite-facies assemblages. However, we distinguish herein mafic gneiss as containing the assemblage hornblende+plagioclase+biotite and comprising schists or weakly foliated metabasites intimately associated with finely interlayered or cross-cutting felsic components. Landewednack schists are typically more strongly foliated, commonly display centimetre-scale, alternating feldspathic and hornblendic layers and characteristically exhibit the assemblage hornblende+ plagioclase+epidote.

The bulk compositions of each of the three facies of the Kennack Gneiss vary significantly in even small outcrops, as do the geometrical relationships of the felsic and mafic components. Nevertheless, the felsic component widely cross-cuts and/or net-veins the mafic, and is clearly the younger overall (Fig. 3a), although primary mesoscopic features are obscured by deformation in many areas. Thus, igneous relationships are typically transposed, resulting in an overall gneissose appearance, both felsic and mafic components having strong, parallel, mineral foliations. At localities where the gneiss is less deformed, a spectrum of primary igneous relationships may be observed, many of which are compatible with commingling of magmas. Outcrops of banded gneiss widely exhibit a streaky texture within which the felsic and mafic components are interfingered in a flame-like fashion, suggesting that the two were probably in a liquid or plastic state when juxtaposed (Fig. 3b). Locally, diffuse, embayed, enclaves of equigranular microgabbro occur within weakly foliated granodiorite (Fig. 3c). 

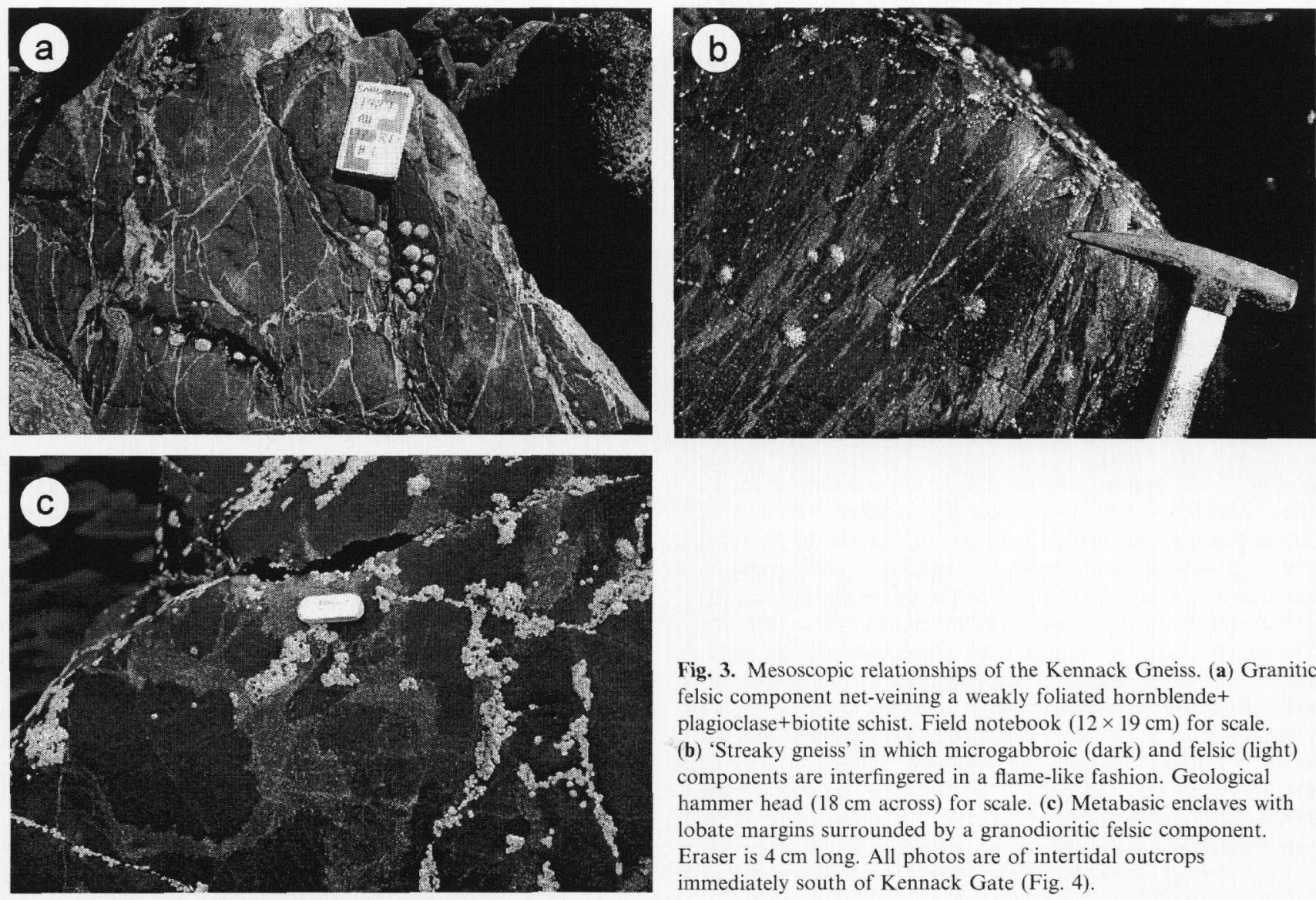

\section{Petrographic characteristics}

Petrographic studies were carried out on 56 specimens of Kennack Gneiss from the SE and west coasts of the peninsula, comprising 29 felsic and 27 mafic components. The felsic rocks vary in modal composition from biotite syenogranite (typical of large bodies of felsic gneiss) to granodiorite, with rare examples of quartz-monzonite (typical of thin silicic veinlets and leucocratic gneissose bands). The majority of the mafic specimens are weakly to strongly foliated hornblendeplagioclase \pm biotite \pm titanite \pm quartz schists. A variation in the mineral assemblages of the mafic facies is observed, and they are subdivided into three types on the basis of distinctive petrographic characteristics. Petrographic aspects of the Kennack Gneiss are recorded in Table 1, but are outlined briefly below

The felsic components. These are dominated by granular monzogranites exhibiting weak anastamosing foliations defined by rare, extensively chloritized, biotite. They crop out mainly along the SE coast and are typically intimately interlayered with, or cut, amphibolitic mafic gneiss. All samples contain porphyroclasts of mesoperthite $(\leq 4 \mathrm{~mm})$, commonly with comminuted boundaries and surrounded by a granoblastic groundmass consisting of intergrown xenoblastic quartz and alkali feldspar exhibiting undulatory extinction. Muscovite occurs sporadically as small interstitial platelets. Accessory phases include rare idioblastic zircon and apatite as inclusions in quartz and feldspar.

Areally restricted and rare fault-controlled bodies of variably foliated syenogranite are exposed along the west coast of
Fig. 3. Mesoscopic relationships of the Kennack Gneiss. (a) Granitic felsic component net-veining a weakly foliated hornblende+ plagioclase+biotite schist. Field notebook $(12 \times 19 \mathrm{~cm})$ for scale. (b) 'Streaky gneiss' in which microgabbroic (dark) and felsic (light) components are interfingered in a flame-like fashion. Geological hammer head (18 cm across) for scale. (c) Metabasic enclaves with lobate margins surrounded by a granodioritic felsic component. Eraser is $4 \mathrm{~cm}$ long. All photos are of intertidal outcrops immediately south of Kennack Gate (Fig. 4).

the peninsula near Kynance Cove and Gew Graze (Fig. 1). In contrast with the typical felsic component described above, they are either fine-grained, recrystallized, two-mica syenogranites, or medium-grained graphic-textured biotite syenogranites. In the former, muscovite occurs as small, apparently replacive, grain aggregates within crystals of feldspar, but also as rare, small, hypidiomorphic grains interstitial to the granular quartz and feldspar, and probably of magmatic origin. Graphic-textured biotite syenogranites are less abundant and are dominated by large $(\leq 8 \mathrm{~mm})$ crystals of alkali feldspar that are cut by anastamosing veinlets of fine-grained, intergrown xenoblastic plagioclase and quartz.

The mafic components. Hornblende and variably saussuritized plagioclase are the major constituents of most specimens of mafic gneiss, although actinolite occurs rarely in the place of hornblende. Titanite is generally abundant and appears to increase with increasing plagioclase and biotite, reflecting variations in bulk-rock $\mathrm{TiO}_{2}$. The mineral assemblages and other salient petrographic characteristics of the mafic gneiss are summarized in Table 1 .

Hornblende - plagioclase \pm biotite \pm titanite schist, commonly exhibiting a gabbroic or microgabbroic texture, is the most abundant facies (group 1), and occurs as slightly elongate pods in weakly banded gneiss. These comprise pale-yellow to green, fibrous to blocky hornblende ( $60-70$ modal \%) set in a matrix of strongly saussuritized plagioclase. Extensively chloritized biotite is rare and forms bladed laths associated with hornblende. Titanite occurs locally as granular polycrystalline masses, but is generally rare. Accessory phases 
Table 1. Petrographic characteristics of the mafic component of the Kennack Gneiss

\begin{tabular}{|c|c|c|c|c|c|c|c|c|c|c|c|}
\hline Sample & $\begin{array}{l}\text { Cluster } \\
\text { group }\end{array}$ & $\begin{array}{l}\text { Petrographic } \\
\text { group }\end{array}$ & $\begin{array}{l}\text { Foliation } \\
\text { intensity }\end{array}$ & $\begin{array}{l}\text { Plagioclase } \\
\% \text { altered }\end{array}$ & Hornblende & Biotite & Titanite & Apatite & Opaques & Quartz & Titanite shape \\
\hline L93-1 & 1 & 1 & M & 90 & $\mathrm{X}$ & $\mathrm{X} *$ & $\mathrm{X}$ & $\mathrm{SE}$ & $\mathrm{X}$ & np & Anhedral \\
\hline L7 -33 & 1 & 1 & M & 100 & $\mathrm{X}$ & $\mathrm{np}$ & $\mathrm{np}$ & SE & $\mathrm{X}$ & np & - \\
\hline L7-35 & 1 & 1 & W & 100 & $\mathrm{X}$ & $\mathrm{x}$ & np & SE & $\mathrm{X}$ & np & - \\
\hline L7-39 & 1 & 1 & $\mathrm{~S}$ & 80 & $X$ & $\mathrm{X}$ & $\mathrm{X}$ & SE & $\mathrm{X}$ & $\mathrm{np}$ & Anhedral \\
\hline L7-44 & 1 & 1 & $\mathrm{~S}$ & 90 & $\mathrm{X}$ & $\mathrm{X}$ & np & SE & $\mathrm{X}$ & np & - \\
\hline L7-46 & 1 & 1 & $\mathrm{~S}$ & 100 & $\mathrm{X}$ & $\operatorname{tr}$ & $\mathrm{X}$ & SE & $\mathrm{X}$ & np & Granular \\
\hline L7-47 & 1 & 1 & W & 100 & $\mathrm{X}$ & $\mathrm{X}$ & $\mathrm{np}$ & SE & $\mathrm{X}$ & np & - \\
\hline L7-56 & 1 & 1 & M & 100 & $\mathrm{X}$ & $\mathrm{np}$ & np & $\mathrm{np}$ & $\mathrm{X}$ & np & - \\
\hline L7 $7-57$ & 1 & 1 & M & 80 & $\mathrm{X}$ & $\operatorname{tr}$ & $\mathrm{np}$ & $\mathrm{SE}$ & $\mathrm{X}$ & $\mathrm{np}$ & - \\
\hline L7-70 & 1 & $2 a$ & M & 40 & $\mathrm{X}$ & $\mathrm{X}$ & $\mathrm{X}$ & SE and AEL & $\mathrm{x}$ & $\operatorname{tr}$ & Anhedral \\
\hline L7-76 & 1 & 1 & $\mathrm{~S}$ & 70 & $\mathrm{X}$ & $\mathrm{X}$ & $\mathrm{np}$ & SE & $\hat{\mathrm{X}}$ & np & - \\
\hline L93-D & 1 & 1 & W-M & 100 & $\mathrm{X}$ & $\operatorname{tr} *$ & $\mathrm{X}$ & SE & $\mathrm{X}$ & np & Anhedral \\
\hline L93-E & 1 & 1 & W & 100 & $\mathrm{X}$ & $\mathrm{X} *$ & $\mathrm{X}$ & SE & $\mathrm{X}$ & np & Anhedral \\
\hline L7-8 & 3 & $2 \mathrm{~b}$ & M & 80 & act & $\mathrm{X}$ & $\mathrm{np}$ & SE & tr & $\mathrm{X}$ & - \\
\hline L7-11 & 2 & $2 \mathrm{a}$ & $\mathrm{S}$ & 40 & $\mathrm{X}$ & $\mathrm{X}$ & $\mathrm{X}$ & SE and AEL & $\mathrm{X}$ & np & Granular \\
\hline L7-22 & 2 & $2 \mathrm{a}$ & W-M & 30 & $\mathrm{X}$ & $\mathrm{X}$ & $\mathrm{tr}$ & AEL & $\mathrm{X}$ & $\operatorname{tr}$ & Granular \\
\hline L7-24 & 2 & $2 a$ & W & 90 & $\mathrm{X}$ & $\mathrm{X} *$ & $\mathrm{tr}$ & $\mathrm{np}$ & $\mathrm{x}$ & $\mathrm{np}$ & Subhedral \\
\hline L7-25 & 2 & $2 \mathrm{a}$ & M-S & 50 & $\mathrm{X}$ & $\operatorname{tr} *$ & $\mathrm{X}$ & $\mathrm{AEL}$ & $\mathrm{x}$ & $\mathrm{x}$ & Anhedral \\
\hline L $7-26$ & 2 & $2 a$ & M & 100 & $\mathrm{X}$ & $\mathrm{X} *$ & $\mathrm{X}$ & SEL & $\mathrm{x}$ & $\operatorname{tr}$ & Subhedral \\
\hline L7 -50 & 3 & $2 b$ & M & 100 & $\mathrm{X}$ & $X *$ & $\mathrm{X}$ & $\mathrm{AEL}$ & $\mathrm{x}$ & $\operatorname{tr}$ & Granular \\
\hline L7 -58 & 3 & $2 b$ & M & 50 & $\mathrm{X}$ & $\mathrm{X}$ & $\mathrm{X}$ & SEL & $\mathrm{X}$ & np & Granular \\
\hline L 7-72 & 2 & $2 a$ & W & 40 & $\mathrm{X}$ & $\mathrm{X}$ & $\mathrm{X}$ & SEL & $\mathrm{x}$ & np & Anhedral \\
\hline L $7-73$ & 3 & $2 \mathrm{~b}$ & M-S & 50 & $\mathrm{X}$ & $x$ & $X$ & SEL & $\mathrm{tr}$ & $X$ & Euhedral \\
\hline L7-77 & 2 & $2 a$ & W & 100 & $\mathrm{X}$ & $\mathrm{X} *$ & tr & SEL & $\mathrm{X}$ & $\mathrm{tr}$ & Anhedral \\
\hline L93-A & 2 & $2 \mathrm{a}$ & W & 90 & $\mathrm{X}$ & $\mathrm{X} *$ & $\mathrm{X}$ & $\mathrm{AEL}$ & $\mathrm{X}$ & $\operatorname{tr}$ & Granular \\
\hline L93-B & 2 & $2 a$ & M & 50 & $X$ & $\mathrm{X}$ & $\mathrm{X}$ & SE & $x$ & $x$ & Granular \\
\hline L93-C & 2 & $2 a$ & W-M & 35 & $\mathrm{X}$ & $\mathrm{X}$ & $\mathrm{X}$ & AEL & $\mathrm{x}$ & $\operatorname{tr}$ & Granular \\
\hline L93-K & 2 & $2 \mathrm{a}$ & W & 90 & $\mathrm{X}$ & $\mathrm{X}^{*}$ & $\mathrm{X}$ & SEL & $\mathrm{X}$ & np & Anhedral \\
\hline
\end{tabular}

Key: W, weak; M, moderate; S, strong; act, actinolite; *chloritized; X, abundant; $x$, rare; tr, trace; np, not present; S, stubby; E, euhedral; A, accicular; EL, elongate.

include abundant xenoblastic magnetite, generally closely associated with the ferromagnesian phases, and abundant apatite as large $(\leq 0.5 \mathrm{~mm})$, dispersed, blocky grains.

Group $2 \mathrm{a}$ is the second-most abundant facies and comprises a fine-grained hornblende+plagioclase+biotite+titanite \pm quartz schist, with yellow to deep-green, hypidiomorphic to xenoblastic, hornblende $(\leq 2.5 \mathrm{~mm})$ with xenoblastic plagioclase. Hornblende is typically mantled by laths of orangebrown biotite, which may have formed through amphibole breakdown. Plagioclase occurs as hypidiomorphic saussuritized grains $(\leq 2 \mathrm{~mm})$, interpreted as remnant phenocrysts, and as small, weakly saussuritized xenoblastic grains in the groundmass. Titanite occurs typically as granular aggregates replacing magnetite and rarely as subhedral grains. Apatite is abundant as acicular crystals embedded in plagioclase and rarely as small idioblastic grains.

Medium-grained, plagioclase-porphyroblastic, biotiteactinolite (or hornblende) schists constitute mafic group $2 \mathrm{~b}$. This facies is rare, occurring as small, elongate and diffuse pods in banded and mafic gneiss. Idiomorphic crystals of either actinolite or hornblende are intergrown with bladed biotite; the former wrap around large $(\leq 2 \mathrm{~mm})$ grains of plagioclase. Hornblende is correlated with an abundance of hypidiomorphic titanite crystals $(\leq 1.5 \mathrm{~mm})$. Plagioclase grains are generally hypidiomorphic and are strongly saussuritized. The groundmass consists of broken, xenoblastic quartz and small, hypidiomorphic antiperthite grains; granophyric texture is common. Accessory minerals include abundant acicular apatite embedded in plagioclase, and rare xenoblastic magnetite.

\section{Analytical methods}

Several hundred milligrams of high-quality zircon were recovered from L93-J, a c. $1 \mathrm{~kg}$ sample of biotite monzogranite from the type-locality of Kennack Sands (Fig. 4). U-Pb analytical methods follow those of Sandeman et al. (1997) and the complete data are recorded in Table 2 and graphically presented in Fig. 5 .

Major and trace element analytical methods (with precision estimates) for samples having the prefix $\mathrm{L} 7$ are outlined in Sandeman $e t$ al. (1997) and the data for three specimens are presented in Table 4. All

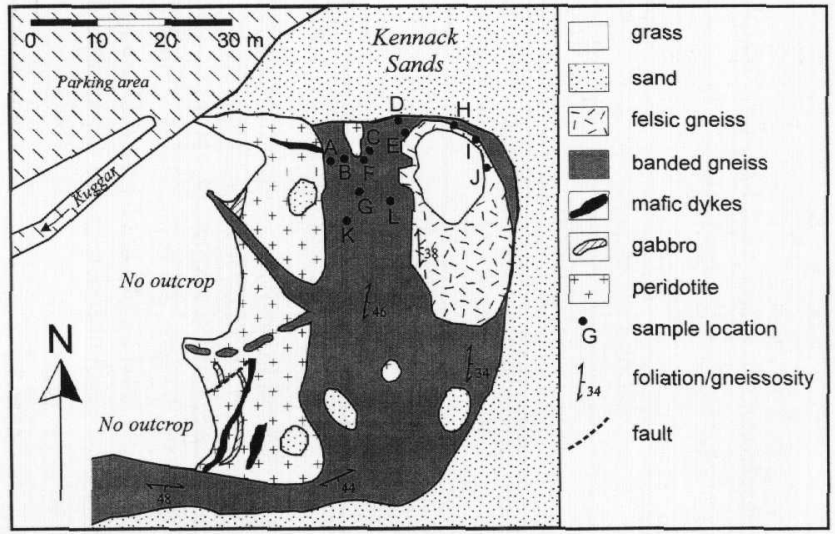

Fig. 4. Geological map of the west side of Kennack Sands (Kennack Gate) showing the locations of samples L93-A through L93-L and of dated specimen L93-J. The divisions of the Kennack Gneiss used in this contribution have been added where appropriate, but the remainder is adapted from Flett (1946). 

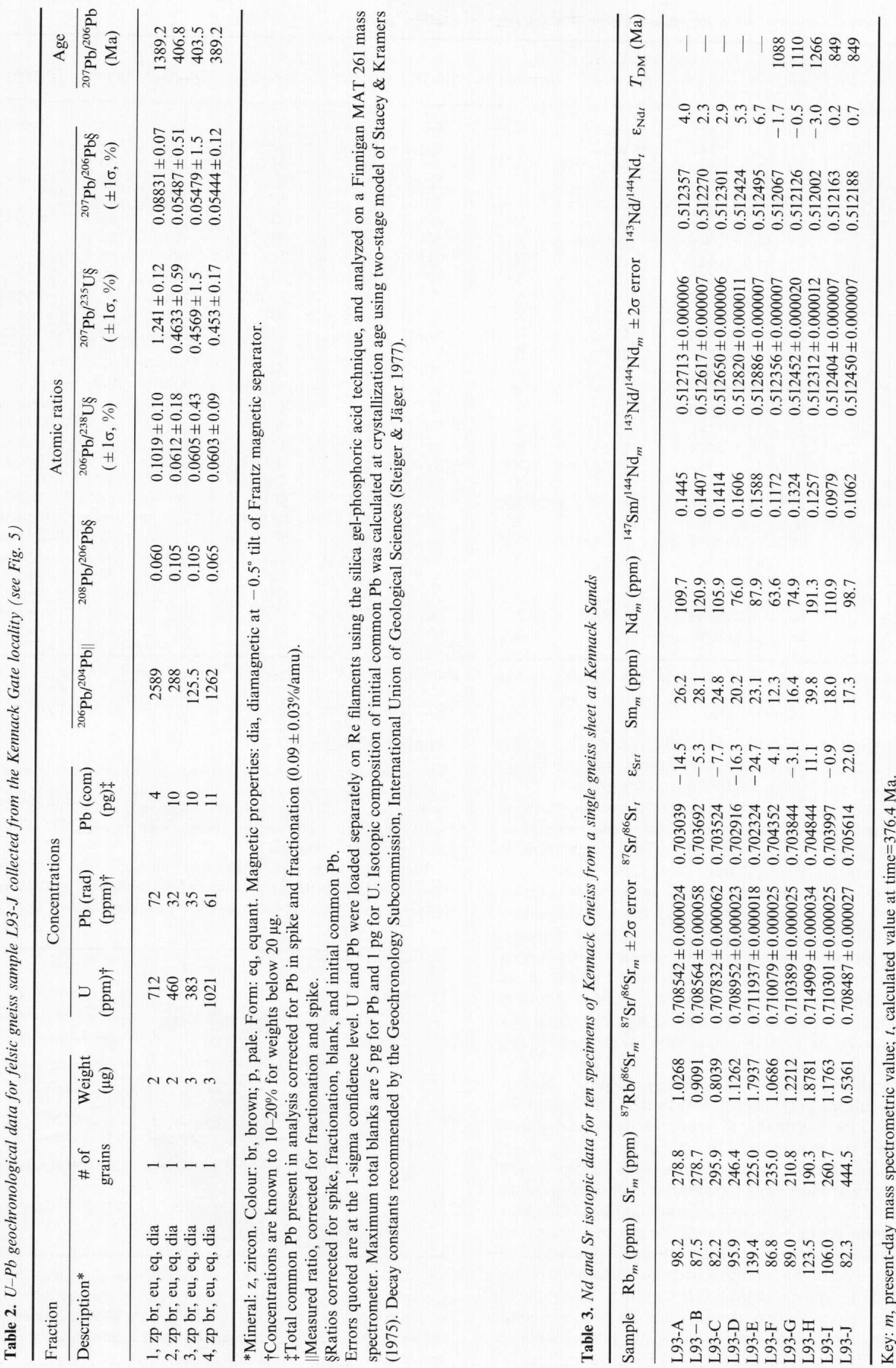


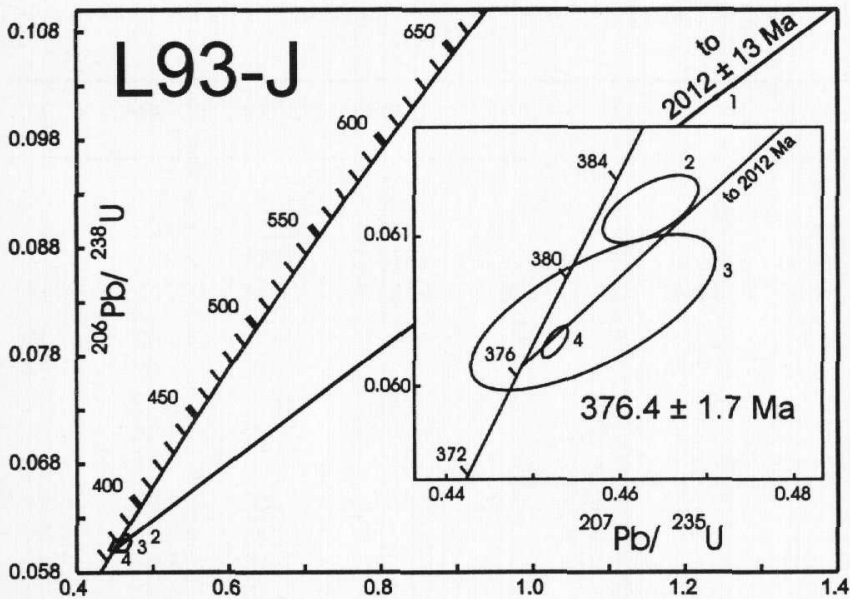

Fig. 5. Concordia plot for four single zircon crystals from Kennack Gneiss sample L93-J (location shown in Fig. 4). Data are presented in Table 2. Ellipses represent $2 \sigma$ errors.

other data can be obtained from the Society Library or the British Library Document Centre, Boston Spa, Wetherby, West Yorkshire LS23 7BQ, UK as Supplementary Publication No. SUP 18149 (6 pages). Analytical methods for major and trace element data (with precision estimates) for all remaining specimens (with prefix L93) are presented in Sandeman et al. (1999).

Isotopic data were obtained at the Geochronological Laboratories of the Geological Survey of Canada following the methodology of Thériault (1990). $\varepsilon_{\mathrm{Nd}}$ values were calculated using a present-day CHUR (chondritic uniform reservoir) composition of ${ }^{143} \mathrm{Nd} /{ }^{144} \mathrm{Nd}=$ 0.512638 and ${ }^{147} \mathrm{Sm} /{ }^{144} \mathrm{Nd}=0.1967$ and an age of $376.4 \mathrm{Ma}$, and the model of DePaolo \& Wasserburg (1976). The reproducibility of the $\varepsilon_{\mathrm{Nd}}$ values was calculated to be better than $0.5 \varepsilon$ units. Nd isotopic data for the ten Kennack Sands samples (L93-A-J) are presented in Table 4. $T_{\mathrm{DM}}$ (time of removal from depleted mantle) ages for the rocks are calculated using the model of DePaolo (1981). $\varepsilon_{\mathrm{Sr}}$ values were calculated to $376.4 \mathrm{Ma}$ using a present-day UR (uniform reservoir) composition of ${ }^{87} \mathrm{Sr} /{ }^{86} \mathrm{Sr}=0.7045$ and ${ }^{87} \mathrm{Rb} /{ }^{86} \mathrm{Sr}=0.0816$. The reproducibility of the $\varepsilon_{\mathrm{Sr}}$ values is calculated to be better than $c .0 .8 \varepsilon$ units. The $\mathrm{Sr}$ isotopic data for the ten samples are also presented in Table 4. Reproducibility of ${ }^{147} \mathrm{Sm} /{ }^{144} \mathrm{Nd}$ and ${ }^{87} \mathrm{Rb} /{ }^{86} \mathrm{Sr}$ values is better than $1 \%$.

\section{$\mathrm{U}-\mathrm{Pb}$ geochronology}

The four analysed zircons regress (York 1969) to yield an upper intercept of $2012 \pm 13 \mathrm{Ma}$, a lower intercept of $376.4 \pm 1.7 \mathrm{Ma}$, with an MSWD of 4.81. Three of the four analysed crystals plot at the lower intercept, whereas the fourth zircon analysis (\#1, Fig. 5, Table 2) plots well up the line. These data suggest that the lower intercept, $376.4 \pm 1.7 \mathrm{Ma}$, represents the time of most significant thermal activity recorded by the sample. In the light of the crustally derived nature of the rock (see below), we suggest that the upper intercept may correspond to the approximate age of the ancient source, whereas the lower intercept is most reasonably interpreted as the age of crystallization of the monzogranitic melt. This interpretation is consistent with the morphology and chemical composition of the analysed crystals. Consequently, this places an upper limit on the age of emplacement of the Kennack Gneiss of $376.4 \pm 1.7 \mathrm{Ma}$, in the late Givetian.

This result is very similar to, but significantly more precise than, previous radiometric ages determined for the Kennack Gneiss. Early $\mathrm{K}-\mathrm{Ar}$ and $\mathrm{Rb}-\mathrm{Sr}$ dates for biotite and horn- blende from the gneiss ranged from 355 to $422 \mathrm{Ma}$ (Dodson 1961; Miller \& Green 1961) and were interpreted as minimum ages. The $\mathrm{Rb}-\mathrm{Sr}$ whole-rock isochron age of $369 \pm 12 \mathrm{Ma}$ determined by Styles \& Rundle (1984), and interpreted by them as a metamorphic age, is very similar to, and overlaps in error with, that presented herein. Sandeman et al. (1995) documented two ${ }^{40} \mathrm{Ar}-{ }^{39} \mathrm{Ar}$ step-heating analyses on hornblende from mafic gneiss at Kennack Sands that yielded plateau ages of $366 \pm 4 \mathrm{Ma}$ and $364 \pm 5 \mathrm{Ma}$, respectively. These were interpreted as metamorphic cooling ages, placing a lower limit on the primary crystallization age of the gneiss, and interpreted as the time at which the gneiss cooled through c. $500^{\circ} \mathrm{C}$ during displacement from an oceanic setting. In conjunction with our new $\mathrm{U}-\mathrm{Pb}$ determination, these ages imply that although the Kennack Gneiss crystallized at $376 \mathrm{Ma}$, it must have cooled rapidly thereafter through the closure temperatures of the whole-rock $\mathrm{Rb}-\mathrm{Sr}$ and hornblende ${ }^{40} \mathrm{Ar}-{ }^{39} \mathrm{Ar}$ systems, and that dynamothermal metamorphism either accompanied or immediately postdated intrusion.

\section{Geochemistry}

A whole-rock geochemical dataset for 56 representative specimens of Kennack Gneiss is evaluated. Most were taken from the east and west coasts of the Lizard Peninsula, but ten were from the IGS drillcore at Kennack Sands. Analyses are most complete for a suite (L93-A-L) comprising six specimens each of mafic and felsic gneiss from the large outcrop at the type-locality of Kennack Sands (Fig. 4), facilitating characterization of the petrochemical relationships among the components of a single gneiss intrusion. In most geochemical diagrams the point-data for all the samples are plotted according to the petrographic subsets outlined above.

\section{Alteration}

The rocks comprising the Kennack Gneiss are dominated by amphibolite facies metamorphic mineral assemblages and textures, and disturbance of their igneous whole-rock chemistry may have occurred (Pearce \& Cann 1973; Wood et al. 1979; Middelburg et al. 1988). However, although the $\mathrm{K}_{2} \mathrm{O}, \mathrm{Rb}, \mathrm{Th}$, and light rare earth element (light REE) contents (Table 4) of the mafic components of the gneiss are much higher than would be expected in typical mid-ocean ridge basalts, they are similar to those of oceanic island tholeiitic or high-K calc-alkaline basalts. Moreover, the abundances of incompatible elements in the felsic components of the gneiss are atypical of granitoids subjected to large-scale metasomatism, many of the large-ion lithophile and most high-field strength elements showing consistent intra-sample behaviour therein. These relationships imply that the contents of these elements are not a result of large-scale metasomatism accompanying metamorphism. The major elements, in contrast, exhibit a moderate degree of scatter, particularly in the more mafic rocks, suggesting that the less mobile trace elements should be utilized for petrogenetic interpretations, even though these may exhibit some mobility during metamorphism (Wood et al. 1979).

\section{Classification}

The felsic components of the gneiss have normative quartz, potassium feldpar and plagioclase compositions typical of 
Table 4. Whole-rock geochemical data for 12 specimens of Kennack Gneiss from the type locality at Kennack Sands, two ophiolitic dykes from near Porthoustock and one Landewednack schist from Cadgwith

Sample L93-F L93-G L93-H L93-I L93-J L93-L L93-A L L93-B $\quad$ L93-C L93-D $\quad$ L93-E $\quad$ L93-K $\quad$ L7-19A L7-20A L7-67

\begin{tabular}{|c|c|c|c|c|c|c|c|c|c|c|c|c|c|c|c|}
\hline Group & 1 & 1 & 1 & 1 & 1 & 1 & 2 & 2 & 2 & 1 & 1 & 2 & & & \\
\hline Rocktype & $\mathrm{FG}$ & FG & $\mathrm{FG}$ & $\mathrm{FG}$ & $\mathrm{FG}$ & $\mathrm{FG}$ & MG & MG & MG & MG & MG & MG & OD & OD & LS \\
\hline Easting & 173458 & 173453 & 173463 & 173460 & 173461 & 173450 & 173445 & 173450 & 173453 & 173459 & 173461 & 173452 & 180700 & 180712 & 172180 \\
\hline Northing & 016487 & 016488 & 016489 & 016488 & 016487 & 016481 & 016479 & 016482 & 016484 & 016490 & 016487 & 016478 & 021100 & 021115 & 014495 \\
\hline $\mathrm{SiO}_{2}$ & 73.4 & 72.1 & 69.7 & 70.8 & 69.3 & 69.4 & 52.3 & 56.6 & 55.0 & 51.2 & 49.2 & 50.7 & 49.8 & 46.3 & 47.30 \\
\hline $\mathrm{TiO}_{2}$ & 0.26 & 0.38 & 0.49 & 0.35 & 0.39 & 0.45 & 1.57 & 1.34 & 1.37 & 1.30 & 1.53 & 2.15 & 1.08 & 1.92 & 2.64 \\
\hline $\mathrm{Al}_{2} \mathrm{O}_{3}$ & 14.2 & 14.2 & 14.4 & 15.3 & 15.7 & 14.4 & 15.7 & 15.9 & 15.8 & 16.8 & 16.5 & 16.1 & 16.7 & 16.7 & 12.90 \\
\hline $\mathrm{FeO}^{\mathrm{T}}$ & 1.4 & 2.0 & 2.8 & 2.1 & 2.2 & 2.9 & 8.4 & 7.2 & 7.6 & 7.6 & 8.2 & 9.1 & 7.35 & 8.40 & 14.01 \\
\hline $\mathrm{MnO}$ & 0.02 & 0.03 & 0.03 & 0.03 & 0.03 & 0.03 & 0.15 & 0.13 & 0.14 & 0.15 & 0.16 & 0.18 & 0.12 & 0.14 & 0.24 \\
\hline $\mathrm{MgO}$ & 0.98 & 1.20 & 1.18 & 1.48 & 1.74 & 1.17 & 6.29 & 4.97 & 5.43 & 7.84 & 8.55 & 6.36 & 8.69 & 8.48 & 6.99 \\
\hline $\mathrm{CaO}$ & 1.50 & 0.89 & 0.72 & 0.44 & 0.77 & 0.54 & 5.75 & 5.62 & 6.63 & 6.25 & 7.12 & 7.00 & 9.06 & 10.24 & 8.60 \\
\hline $\mathrm{Na}_{2} \mathrm{O}$ & 3.70 & 4.10 & 3.60 & 4.90 & 4.90 & 3.20 & 3.90 & 3.40 & 3.60 & 3.30 & 2.30 & 3.70 & 3.33 & 3.52 & 3.40 \\
\hline $\mathrm{K}_{2} \mathrm{O}$ & 3.39 & 3.63 & 4.86 & 2.93 & 2.86 & 5.61 & 2.31 & 2.17 & 1.88 & 2.12 & 2.67 & 1.70 & 0.27 & 0.27 & 0.26 \\
\hline $\mathrm{P}_{2} \mathrm{O}_{5}$ & 0.10 & 0.10 & 0.20 & 0.11 & 0.12 & 0.20 & 0.28 & 0.25 & 0.25 & 0.18 & 0.23 & 0.34 & 0.14 & 0.32 & 0.30 \\
\hline LOI & 0.7 & 1.0 & 1.1 & 1.4 & 1.5 & 1.1 & 2.1 & 1.5 & 0.9 & 2.5 & 2.7 & 1.8 & 2.47 & 1.25 & 0.99 \\
\hline $\mathrm{Cr}$ & 27 & 30 & 17 & 33 & 34 & 15 & 173 & 164 & 164 & 281 & 292 & 82 & 328 & 254 & 79 \\
\hline $\mathrm{Ni}$ & 13 & 13 & 16 & 32 & 35 & 47 & 85 & 61 & 56 & 89 & 120 & 48 & 121 & 103 & 24 \\
\hline $\mathrm{Sc}$ & 4.2 & 6.0 & 6.0 & 4.8 & 6.2 & 6.1 & 27.0 & 23.0 & 25.0 & 28.0 & 31.0 & 32.0 & 31 & na & 53 \\
\hline V & 35 & 34 & 42 & 42 & 39 & 55 & 202 & 193 & 197 & 204 & 227 & 264 & 213 & 257 & 483 \\
\hline $\mathrm{Cu}$ & bd & 11 & 11 & 10 & bd & 22 & 15 & 17 & 11 & 21 & 17 & 22 & 1 & 20 & 19 \\
\hline $\mathrm{Pb}$ & 16 & 15 & 23 & 8 & 13 & 25 & 6 & 8 & 7 & 2 & 2 & 4 & 6 & 5 & 6 \\
\hline $\mathrm{Zn}$ & 20 & 23 & 34 & 26 & 34 & 34 & 60 & 59 & 50 & 54 & 53 & 52 & 44 & 47 & 97 \\
\hline $\mathrm{Rb}$ & 86 & 89 & 130 & 100 & 84 & 180 & 100 & 94 & 83 & 100 & 150 & 80 & 1 & 4 & 2 \\
\hline $\mathrm{Cs}$ & 6.3 & 3.3 & 2.2 & 1.5 & 1.9 & 3.0 & 9.3 & 6.6 & 6.9 & 17.0 & 17.0 & 9.2 & 5.5 & 2.2 & 1.10 \\
\hline $\mathrm{Ba}$ & 669 & 504 & 704 & 749 & 825 & 756 & 231 & 248 & 213 & 153 & 160 & 132 & 17 & 34 & 14 \\
\hline $\mathrm{Sr}$ & 272 & 245 & 225 & 311 & 515 & 208 & 297 & 305 & 317 & 273 & 248 & 405 & 247 & 313 & 147 \\
\hline $\mathrm{Ga}$ & 16 & 16 & 18 & 17 & 18 & 19 & 18 & 19 & 18 & 17 & 16 & 20 & 13 & 18 & 18 \\
\hline $\mathrm{Ta}$ & 1.6 & 0.8 & 1.5 & 1.4 & 1.5 & 1.8 & 1.0 & 1.4 & 1.1 & 0.4 & 0.5 & 1.1 & na & na & na \\
\hline $\mathrm{Nb}$ & 5.2 & 8.2 & 15.0 & 5.8 & 6.7 & 17.0 & 9.7 & 11.0 & 9.2 & 4.0 & 5.1 & 10.0 & 1.4 & 3.9 & 1.0 \\
\hline Hf & 3.0 & 2.9 & 7.7 & 4.3 & 4.4 & 7.4 & 4.5 & 5.0 & 5.3 & 3.5 & 4.2 & 5.3 & 1.7 & 2.9 & 1.68 \\
\hline $\mathrm{Zr}$ & 117 & 109 & 324 & 187 & 193 & 330 & 214 & 225 & 209 & 141 & 186 & 259 & 103 & 125 & 177 \\
\hline Y & 7.1 & 11.0 & 27.0 & 12.0 & 12.0 & 29.0 & 36.0 & 36.0 & 33.0 & 30.0 & 36.0 & 41.0 & 23 & 30 & 41 \\
\hline Th & 12.0 & 8.0 & 27.0 & 14.0 & 12.0 & 25.0 & 3.6 & 6.0 & 4.6 & 1.7 & 1.3 & 2.9 & 0.08 & 0.05 & 0.15 \\
\hline $\mathrm{U}$ & 3.60 & 3.40 & 4.00 & 2.60 & 2.70 & 4.00 & 1.50 & 2.40 & 1.80 & 0.80 & 0.51 & 1.20 & 0.12 & 0.05 & bd \\
\hline $\mathrm{La}$ & 16.0 & 14.0 & 41.0 & 32.0 & 30.0 & 42.0 & 18.0 & 21.0 & 18.0 & 9.7 & 10.0 & 17.0 & 3.10 & 6.56 & 7.67 \\
\hline $\mathrm{Ce}$ & 37.0 & 32.0 & 89.0 & 61.0 & 58.0 & 95.0 & 42.0 & 50.0 & 43.0 & 24.0 & 28.0 & 41.0 & 10.22 & 21.02 & 22.94 \\
\hline $\operatorname{Pr}$ & 4.00 & 3.90 & 11.00 & 6.60 & 6.00 & 11.00 & 5.70 & 6.50 & 5.60 & 3.60 & 4.10 & 5.60 & 1.77 & 3.38 & 3.80 \\
\hline $\mathrm{Nd}$ & 14.0 & 14.0 & 40.0 & 23.0 & 21.0 & 42.0 & 24.0 & 26.0 & 23.0 & 16.0 & 18.0 & 24.0 & 9.31 & 16.26 & 19.35 \\
\hline $\mathrm{Sm}$ & 2.70 & 3.20 & 8.30 & 3.70 & 3.50 & 8.40 & 6.00 & 5.70 & 5.30 & 4.00 & 4.90 & 6.50 & 2.87 & 4.65 & 6.28 \\
\hline $\mathrm{Eu}$ & 0.51 & 0.55 & 0.97 & 0.47 & 0.54 & 0.82 & 1.70 & 1.50 & 1.50 & 1.40 & 1.70 & 1.90 & 1.07 & 1.71 & 2.27 \\
\hline $\mathrm{Gd}$ & 1.90 & 2.80 & 6.90 & 2.60 & 2.80 & 6.80 & 6.50 & 6.20 & 5.80 & 4.80 & 6.10 & 7.20 & 3.17 & 6.34 & 7.69 \\
\hline $\mathrm{Tb}$ & 0.26 & 0.45 & 1.00 & 0.41 & 0.45 & 1.10 & 1.10 & 1.00 & 0.97 & 0.83 & 1.00 & 1.20 & 0.61 & 0.88 & 1.41 \\
\hline Dy & 1.30 & 2.20 & 5.10 & 2.00 & 2.20 & 5.20 & 6.00 & 5.80 & 5.50 & 4.90 & 5.80 & 6.70 & 4.05 & 5.78 & 8.71 \\
\hline Ho & 0.22 & 0.41 & 0.97 & 0.39 & 0.45 & 0.96 & 1.30 & 1.20 & 1.20 & 1.00 & 1.20 & 1.40 & 0.85 & 1.21 & 1.80 \\
\hline $\mathrm{Er}$ & 0.58 & 0.95 & 2.40 & 1.10 & 1.20 & 2.50 & 3.50 & 3.20 & 3.10 & 2.80 & 3.60 & 3.80 & 2.49 & 3.64 & 5.21 \\
\hline $\mathrm{Tm}$ & 0.09 & 0.13 & 0.35 & 0.17 & 0.18 & 0.38 & 0.52 & 0.47 & 0.47 & 0.42 & 0.53 & 0.56 & 0.34 & 0.49 & 0.72 \\
\hline $\mathrm{Yb}$ & 0.57 & 0.79 & 2.20 & 1.10 & 1.20 & 2.40 & 3.20 & 2.90 & 3.00 & 2.70 & 3.30 & 3.70 & 2.07 & 3.27 & 4.66 \\
\hline $\mathrm{Lu}$ & 0.09 & 0.11 & 0.34 & 0.17 & 0.18 & 0.37 & 0.50 & 0.45 & 0.44 & 0.41 & 0.50 & 0.54 & 0.29 & 0.47 & 0.66 \\
\hline $\mathrm{Eu} / \mathrm{Eu} *$ & 0.73 & 0.54 & 0.39 & 0.46 & 0.52 & 0.34 & - & 0.78 & - & - & - & - & - & - & - \\
\hline $\mathrm{Th} / \mathrm{Yb}$ & 21.05 & 10.13 & 12.27 & 12.73 & 10.00 & 10.42 & 1.13 & 2.07 & 1.53 & 0.63 & 0.39 & 0.78 & 0.04 & 0.01 & 0.04 \\
\hline $\mathrm{A} / \mathrm{CNK}$ & 1.14 & 1.16 & 1.15 & 1.27 & 1.25 & 1.17 & - & - & - & - & - & - & - & - & - \\
\hline
\end{tabular}

The remainder of the data can be obtained from the Society Library or the British Library Document Supply Centre, Boston Spa, Wetherby, West Yorkshire LS23 7BQ, UK as Supplementary Publication No. SUP18149 (6 pages). All major elements in wt \% oxide and trace elements in ppm. Key: MG, mafic gneiss; FG, felsic gneiss; OD, ophiolitic dyke; LS, Landewednack Schist; na, not analysed; bd, below detection. Eastings and northings refer to NGR values for the Institute of Geological Sciences map sheet 359.

granites and granodiorites, although in the diagram of Barker (1979) they plot predominantly as granites, with rare trondhjemites (Fig. 6). The rocks are rich in $\mathrm{SiO}_{2}(68.9-$ $77.0 \mathrm{wt} \%), \mathrm{K}_{2} \mathrm{O}(2.86-6.26 \mathrm{wt} \%)$ and $\mathrm{Rb}(68-186 \mathrm{ppm})$, but poor in $\mathrm{FeO}^{\mathrm{T}}(0.19-2.90 \mathrm{wt} \%)$, and do not conform to the trondhjemitic compositions previously inferred (see Strong et al. 1975; Malpas \& Langdon 1987). The granites have marginally metaluminous to markedly peraluminous compositions, with $\mathrm{A} / \mathrm{CNK}$ (molecular $\mathrm{Al}_{2} \mathrm{O}_{3}$ / $\left.\left(\mathrm{K}_{2} \mathrm{O}+\mathrm{Na}_{2} \mathrm{O}+\mathrm{CaO}\right)\right)=0.95-1.27$ and normative corundum values of $\leq 3.49 \%$. The more silica-poor rocks are typically the more peraluminous.

The absence of original mineral assemblages in the mafic rocks precludes their modal classification, but CIPW 


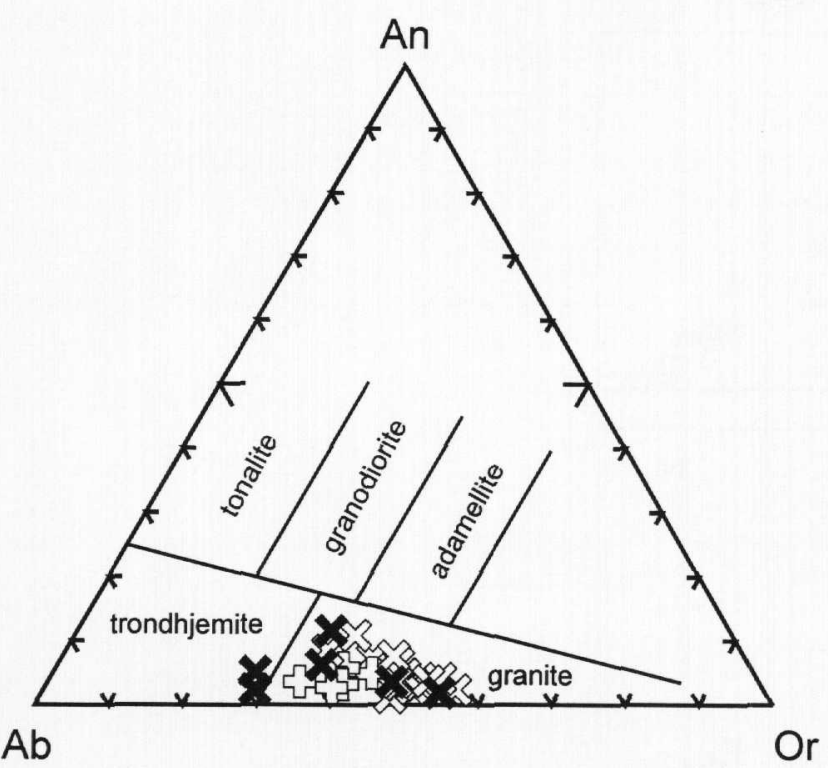

Fig. 6. Normative orthoclase-albite-anorthite plot (after Barker 1979) for samples of the felsic component of the Kennack Gneiss. Open cross symbols are samples of felsic gneiss from the SE coast, open crosses are samples from the west coast, and filled symbols are those from the Kennack Sands type-locality.

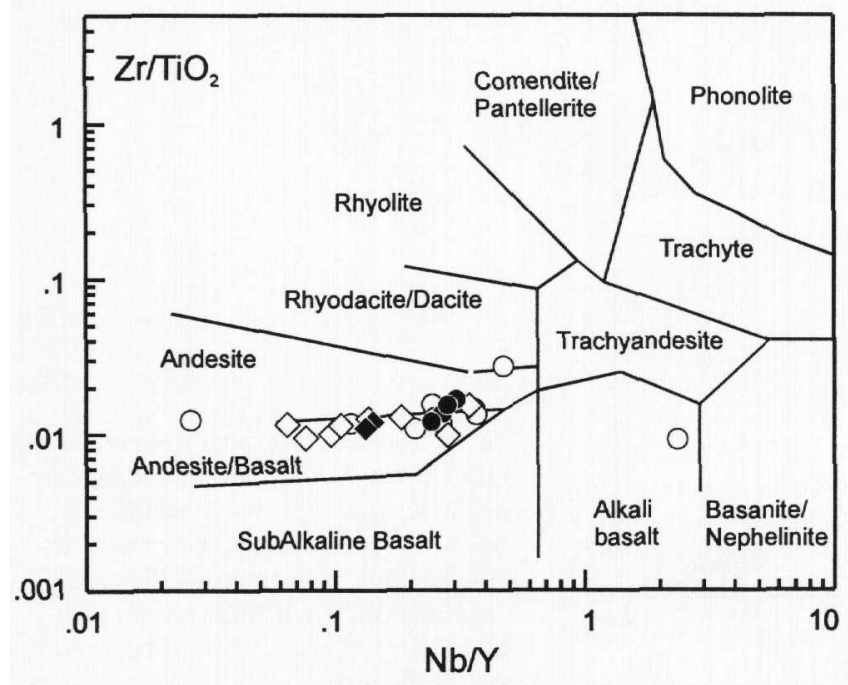

Fig. 7. $\mathrm{Zr} / \mathrm{TiO}_{2}$ versus $\mathrm{Nb} / \mathrm{Y}$ diagram (Winchester \& Floyd 1977) for samples of the mafic component of the Kennack Gneiss showing their basaltic to andesitic compositions. Group 1 mafic gneisses are plotted as diamonds and those of group 2 as circles. Filled symbols represent samples from the Kennack Sands locality.

normative calculations demonstrate that the majority are hypersthene- and/or quartz-normative. Eleven are very weakly nepheline-normative, probably reflecting major element mobility during metamorphism. Overall, the mafic components of the gneiss are alkali-rich, ranging from basanites to basaltic trachy-andesites (IUGS TAS diagram: not shown), and plot as basalts and andesites in the immobile element classification diagram of Winchester \& Floyd (1977; Fig. 7). Group 1 mafic gneisses are largely basaltic, with higher $\mathrm{Mg}$ nos. (molecular $\mathrm{Mg} /(\mathrm{Mg}+\mathrm{Fe}) ; \mathrm{Fe}$ as $\left.\mathrm{FeO}^{\mathrm{T}}\right)$ and lower silica contents than group 2 rocks, which represent basaltic andesites and andesites. All rocks of the mafic suite are tholeiitic (e.g.
Miyashiro 1974), although other classification methods (e.g. Irvine \& Barager 1971) suggest a calc-alkaline affinity. Cluster analysis of the available data for the mafic component of the Kennack Gneiss defines three subsets that closely correspond to the petrographic subdivisions defined earlier (see Table 1). The following geochemical discussion will emphasize these various subsets.

\section{Bivariate diagrams}

The Kennack Gneiss spans a wide range of silica content (44-77 wt \%: hydrous), but with a gap between c. 58 and $68 \mathrm{wt} \% \mathrm{SiO}_{2}$ within which only two samples plot (Figs 8 \& 9). Overall, the granitic rocks appear to represent a geochemical continuum, although felsic gneisses from the west coast are commonly more silicic and appear to represent more differentiated melts. The behaviour of the major and transition elements in the felsic components is dominated by linear covariance with respect to silica. In the mafic suite as a whole, however, the major and transition elements show no systematic overall trends versus silica (Fig. 8). Rocks of mafic group 2 exhibit roughly negative linear covariation of most major and transition elements with silica, whereas those of group 1 occupy irregularly shaped fields with no systematic relationship between major and transition elements and $\mathrm{SiO}_{2}$. In general, rocks of group 1 have higher $\mathrm{MgO}, \mathrm{Na}_{2} \mathrm{O}, \mathrm{Cr}$ and $\mathrm{Ni}$ and lower $\mathrm{FeO}^{\mathrm{T}}, \mathrm{TiO}_{2}, \mathrm{P}_{2} \mathrm{O}_{5}, \mathrm{Sc}$ and $\mathrm{V}$ than those of group 2 at comparable silica contents.

In general, $\mathrm{U}, \mathrm{Th}$ and the light $\mathrm{REE}(\mathrm{La}-\mathrm{Nd})$ exhibit, respectively, negative and positive linear behaviour with silica in the felsic and mafic (groups 1 \& 2) components (Fig. 9). However, the middle and heavy REE exhibit no apparent systematic variation versus silica in both mafic and felsic rocks. In the felsic units, $\mathrm{Zr}$ and $\mathrm{Hf}$, both of which are partitioned strongly into zircon, show a clear negative covariation with silica, whereas the other HFSE, $\mathrm{Ta}, \mathrm{Nb}$ and $\mathrm{Y}$, display scattered variations. These elements exhibit large ranges (Table 3) in both mafic (groups 1 \& 2) and felsic components of the gneiss, a feature that is not likely to have resulted from metamorphic recrystallization and is not compatible with derivation through simple partial melting or fractional crystallization of cogenetic magmas. Rocks of mafic group 1 are generally characterized by lower HFSE and REE contents than those of group 2.

Rocks having intermediate major element contents are rare. Major and trace element abundances for these specimens are generally intermediate between the felsic and mafic end members (Figs $8 \&$ 9), but exhibit no systematic behaviour.

\section{Rare earth element variations}

The granitic rocks have light REE enriched patterns (Fig. 10a), with $\mathrm{La}_{\mathrm{N}} / \mathrm{Lu}_{\mathrm{N}}=7.50-27.89$, and prominent negative $\mathrm{Eu}$ anomalies $(\mathrm{Eu} / \mathrm{Eu} *=0.21-0.73)$. The light $\mathrm{REE}$ segments ( $\mathrm{La}-\mathrm{Sm})$ of the patterns are generally mutually parallel, and broadly exhibit an overall decrease in light REE with increasing $\mathrm{SiO}_{2}$. Typically, however, the patterns of the more silicarich rocks incorporate flatter heavy REE segments. The magnitude of the negative Eu anomalies shows no systematic overall relationship with $\mathrm{SiO}_{2}$, although the most silica-poor granites commonly have large negative Eu anomalies. The one specimen of felsic gneiss from the west coast has the flattest REE pattern, with a low $\mathrm{La}_{\mathrm{N}} / \mathrm{Lu}_{\mathrm{N}}$ ratio of 7.50 . 

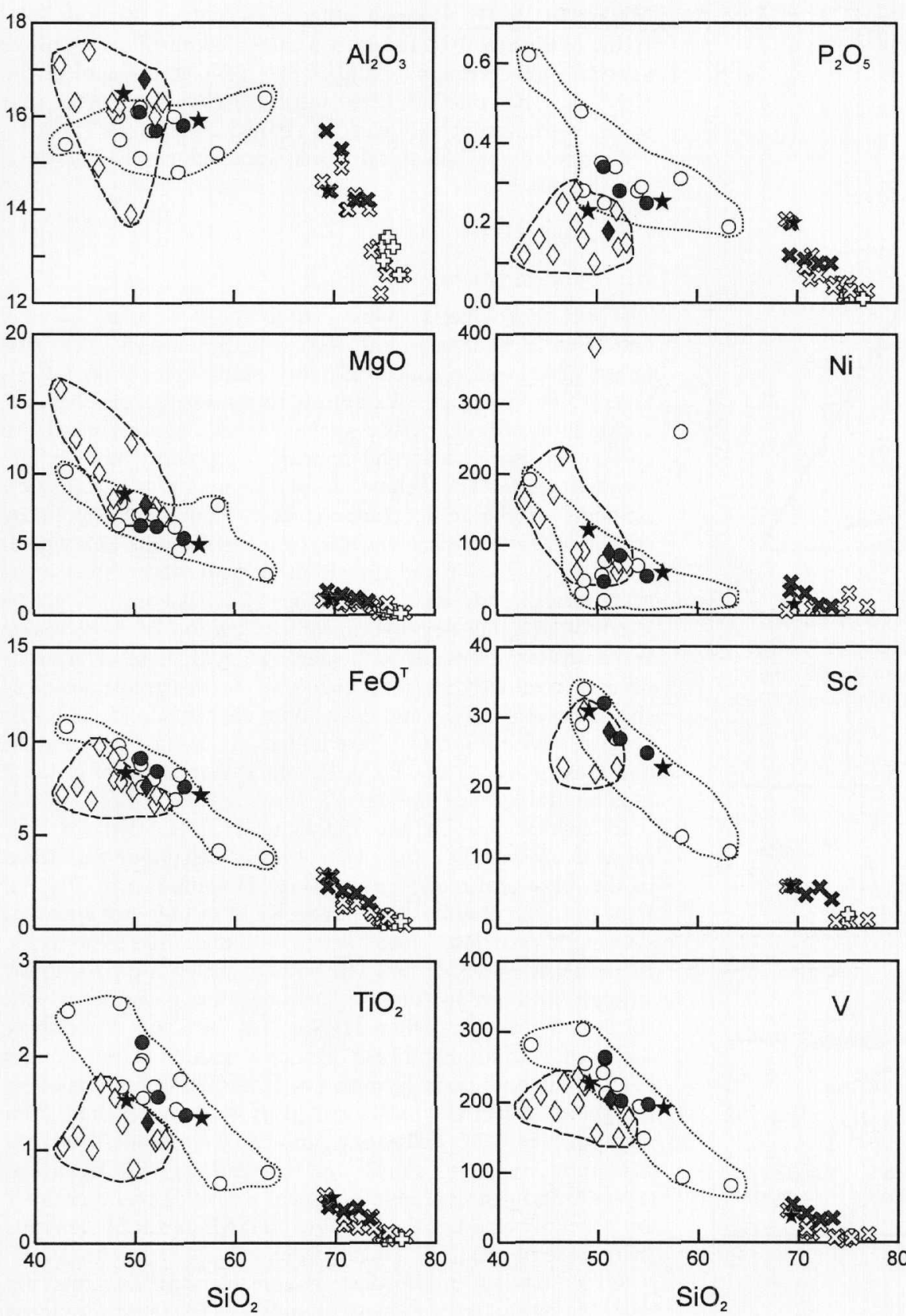

Fig. 8. Selected major and compatible trace element Harker variation diagrams for the Kennack Gneiss. Symbols as in Figs 6 and 7, except: shaded crosses are felsic gneisses from Kennack Sands; and black stars represent three specimens (L93-E, L93-H and L93-B) discussed later in the text.
The mafic rocks exhibit light REE enriched patterns having mildly fractionated REE concentrations with $\mathrm{La}_{N} / \mathrm{Lu}_{\mathrm{N}}=1.72-$ 5.00. The heavy REE segments of the patterns generally parallel one another, although cross-over of the light REE segments of the patterns occurs (Fig. 10b). Some of the samples have a minor negative $\mathrm{Eu}$ anomaly (Eu/Eu* $\geq 0.78$ ), suggesting restricted plagioclase fractionation. Generally, REE abundances increase with decreasing $\mathrm{MgO}$. Samples belonging to group 1 have lower abundances of the REE and typically slightly lower $\mathrm{LaN} / \mathrm{LuN}$ ratios $(1.72-4.76)$. The two samples having intermediate major and trace element abundances are characterized by light REE enriched patterns $\left(\mathrm{La}_{\mathrm{N}} / \mathrm{Lu}_{\mathrm{N}}=\right.$ 14.36 and 16.87) and variable negative $\mathrm{Eu}$ anomalies, with $\mathrm{Eu} / \mathrm{Eu} * \geq 0.51$.
Sm-Nd and $R b-S r$ isotope data

The isotopic data for collected from ten specimens for a single gneiss intrusion at Kennack Sands are presented in Table 3, and shown graphically in Fig. 11. $\varepsilon_{\mathrm{Nd}}$ values have been recalculated (DePaolo \& Wasserburg 1976) to 376.4 Ma based on the zircon $\mathrm{U}-\mathrm{Pb}$ date reported herein. These data reveal highly variable $\varepsilon_{\mathrm{Nd} t=376 \mathrm{Ma}}$ and $\varepsilon_{\mathrm{Sr} t=376 \mathrm{Ma}}$ values, the five samples of the mafic component of the gneiss having $\varepsilon_{\mathrm{Nd} t=376 \mathrm{Ma}}=+2.3$ to +6.7 and $\varepsilon_{\mathrm{Sr} t=376 \mathrm{Ma}}=-5.3$ to -24.7 (Table 3; Fig. 11). The group 1 mafic rocks appear to have higher $\varepsilon_{\mathrm{Nd} t}$ and lower $\varepsilon_{\mathrm{Sr} t}$ than those of group 2 . In contrast, the five samples of the felsic component exhibit $\varepsilon_{\mathrm{Nd} t=376 \mathrm{Ma}}=$ +0.7 to -3.0 and corresponding $\varepsilon_{\mathrm{Sr} t=376 \mathrm{Ma}}=-3.1$ to 23.2 (Table 3; Fig. 11). 

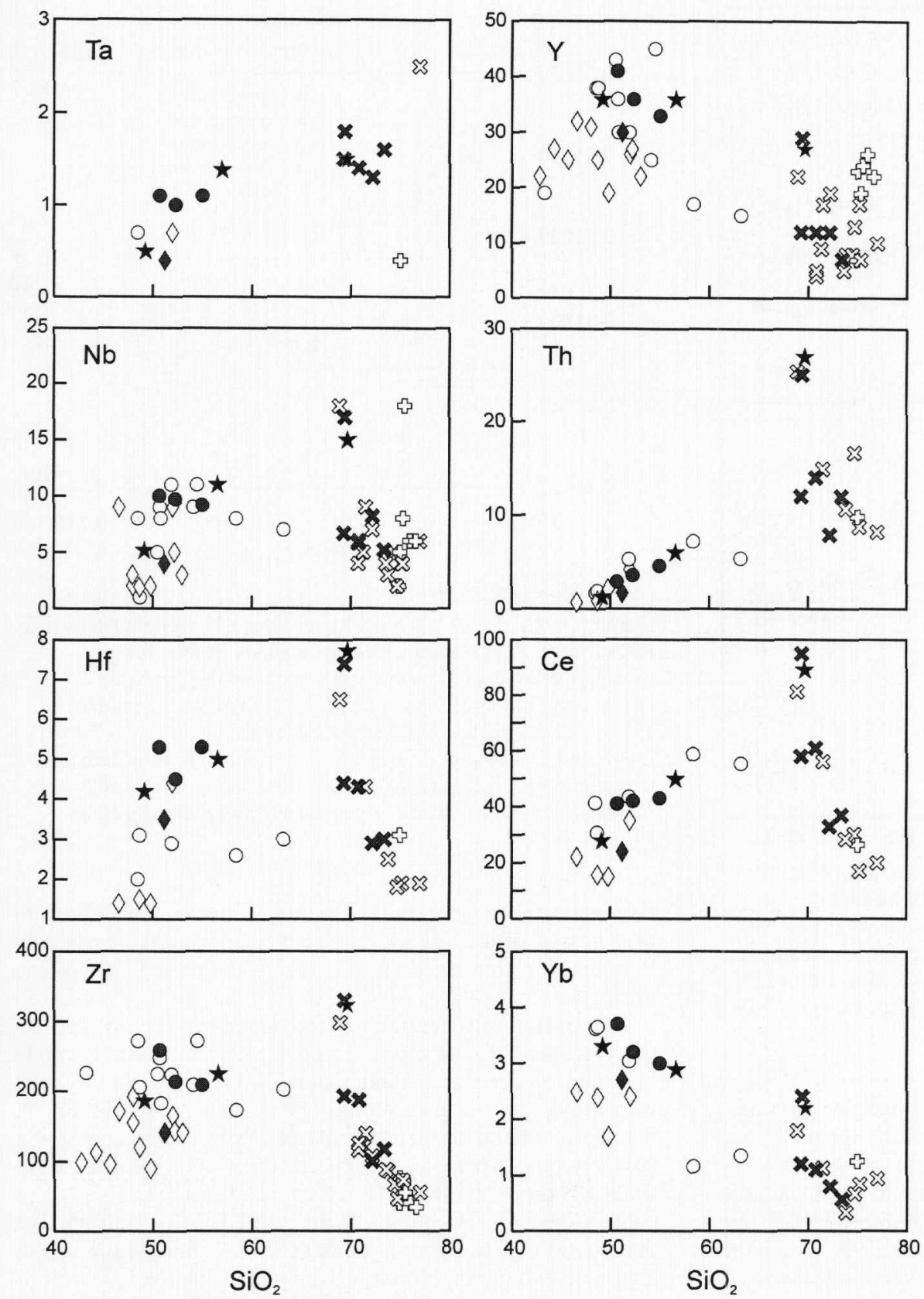

Fig. 9. Selected incompatible trace element Harker variation diagrams for the Kennack Gneiss. Symbols as in Figs 6,7 and 8.

$T_{\mathrm{DM}}$ ages for the felsic gneiss, calculated after DePaolo (1981), range from 849 to $1266 \mathrm{Ma}$, implying derivation from a crustal source that had separated from a depleted mantle source during the Meso- and Neoproterozoic. These model ages overlap with the $1177-1658 \mathrm{Ma} \mathrm{Sm}-\mathrm{Nd} T_{\mathrm{DM}}$ ages presented by Floyd et al. (1991) for clastic metasedimentary rocks of the Gramscatho Group.

\section{Discussion}

\section{Summary of field and petrographic relationships}

Previous investigations (Teall 1887; Flett 1946; Strong et al. 1975; Malpas \& Langdon 1987) have established the intrusive nature of the Kennack Gneiss. That it was generated by commingling of magmas, however, has not been widely accepted, because it is commonly in fault contact with the host rocks, and is typically strongly deformed, with gneissose textures. Exposures along the coast south of Cadgwith are highly strained such that original cross-cutting relationships are commonly transposed parallel to the enveloping surfaces of the enclosing fault zones. Bodies cropping out north of Cadgwith, however, are less deformed, and cross-cutting relationships and primary features are better preserved.

Although the field divisions of the gneiss advocated herein are of necessity subjective, it is clear that while the mafic component predominates, gradations from mafic- to felsicdominated gneiss are widely observed. Relationships between the mafic and felsic components are variable, but primary igneous textures such as net-veining of the mafic by the felsic component, 'flame-like' interfingering of the two, and features such as diffuse, embayed, mafic enclaves in the felsic 


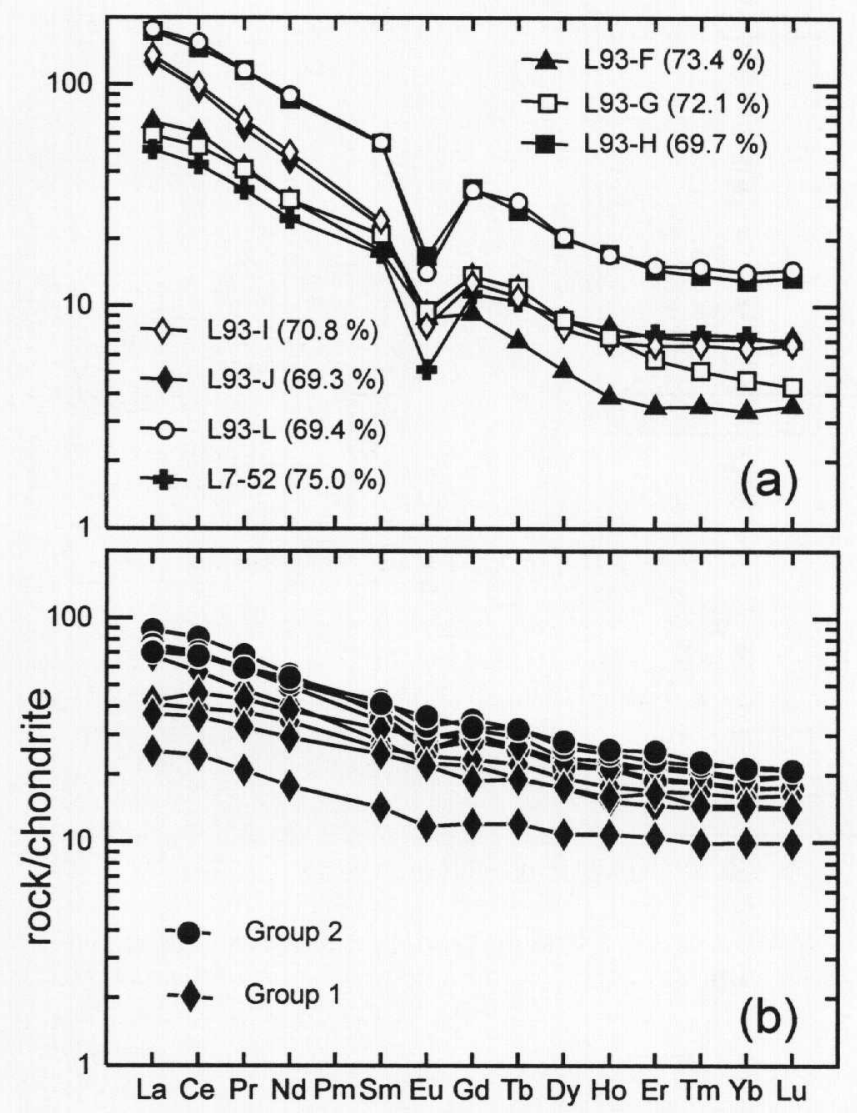

Fig. 10. (a) Rare earth element diagram for six samples of the felsic component of the Kennack Gneiss from the type locality at Kennack Sands, and one from the west coast of the peninsula. $\mathrm{SiO}_{2}$ contents are shown in parentheses. (b) Rare earth element diagram for eight samples of the mafic component of the Kennack Gneiss including four each of groups 1 and 2. Normalizing values are from Sun \& McDonough (1989).

component, support the occurrence of both magma commingling and mixing. Both components, particularly the mafic, are internally variable in texture and composition. Such variability is typical in the mafic component of a commingled magmatic association (Bacon 1986; Frost \& Mahood 1987; Babarin 1988; Vernon et al. 1988; Babarin \& Didier 1996), and the mafic component of the Kennack Gneiss is, from our field and petrographic observations, inferred to record variations in both finite strain and bulk composition prior to deformation. Thus, mafic schists of group 1 (Table 1) exhibit high proportions of hornblende to plagioclase, generally contain only minor quartz, biotite and titanite, and have abundant opaque minerals, features distinguishing them from the mafic schists of group 2. Moreover, rocks of group 1 almost exclusively display large ( $\leq 0.5 \mathrm{~mm}$ long), stubby, hypidiomorphic, apatite grains, implying slow cooling and protracted crystallization. Elongate pods of this facies are interpreted to represent weakly deformed, rheologically competent, enclaves of largely crystallized mafic magma within a monzogranite host. In contrast, schists of mafic group 2 commonly contain large plagioclase grains more calcic than the groundmass plagioclase, and interpreted as relict magmatic phenocysts, as well as both abundant acicular apatite, indicative of rapid cooling (Bacon 1986), and sparse, equant apatite. The abundance of biotite and the occurrence of rare quartz along with acicular apatite in

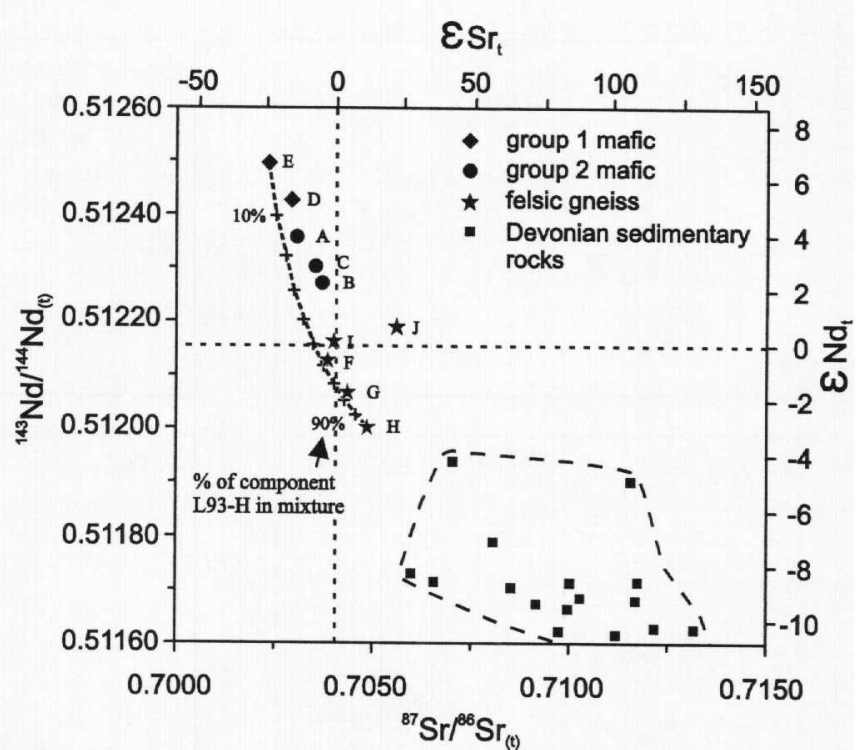

Fig. 11. Plot of ${ }^{143} \mathrm{Nd} /{ }^{144} \mathrm{Nd}$ versus ${ }^{87} \mathrm{Sr} /{ }^{86} \mathrm{Sr}(T=375 \mathrm{Ma})$ for 10 samples (labelled L93-A-J but without their L93 prefix) of Kennack Gneiss from a single sheet at Kennack Sands. Shown for comparison are data for sedimentary rocks of the Devonian Gramscatho Group (Floyd et al. 1991; Darbyshire \& Sheppard 1994). The dashed line represents a calculated mixing curve between L93-E and $\mathrm{L} 93-\mathrm{H}$ and the crosses the calculated values of mixtures representing $10 \%$ through $90 \%$ of the silicic component mixed with the mafic component. The compositions of the end-members are given in Table 4

these samples suggest that they may represent metamorphically recrystallized, microgranular mafic enclaves, or partially hybridized commingled mafic magma, dispersed in a silicic host.

The overall distribution of the Kennack Gneiss and its macroscopic textures indicate that intrusion occurred largely as either sill-like sheets along major, NW-verging thrust faults or as dyke-like bodies along NW-trending vertical faults. Schistose alteration zones along steep gneiss-peridotite contacts, and widespread hematitization of peridotite above shallowly dipping intrusions of Kennack Gneiss, support these conclusions. Gneiss bodies along the SE coast intrude the peridotite or occur within a major thrust zone within which gneissose and mineral foliations, as well as the overall trend of the intrusions, dip shallowly $\left(c .30^{\circ}\right)$ to the SE. In the intertidal zone at the southern end of Kennack Sands (Figs 1 \& 4), a large block of Kennack Gneiss protrudes from the sand and provides an example of the overall structure and form of the intrusions. Here, a $5 \mathrm{~m}$ thick sheet of foliated biotite monzogranite dips at a low angle to the ESE and is mantled above and below by horizons of discontinuously banded gneiss. The upper contact of this composite sheet is not exposed. Similar relationships between the two gneiss components can be observed at variable scales at several coastal exposures from Kildown Cove to Kennack Sands, and imply diapiric emplacement of the granitic magma, simultaneous with displacement of the hanging-wall to the NNW.

The widespread occurrence of the felsic component as homogeneous core-zones within the sill-like sheets, and typically bounded by sheaths of banded or mafic gneiss, implies that the observed areal relationships of the gneiss components 
reflect their original intrusive distribution. We conclude that this pattern records a transition from axial felsic magma, through commingled magmas, into marginal mafic magma. Zones of banded gneiss which are not pervasively deformed and preserve primary igneous textures, therefore, may be interpreted as zones of commingling between mafic and felsic magmas. The proportion of the felsic component of the Kennack Gneiss increases upwards from the basal thrust, a feature interpreted to reflect the lower density of the granitic magma. The commingled assemblage would eventually have attained a level where the mafic magma attained buoyant equilibrium whereas the felsic magma continued to ascend, shedding its mafic sheath (Sparks \& Marshall 1986), a process which may have resulted in the homogeneous bodies of granite on the west coast of the peninsula.

The observations we document indicate that the intrusive forms and structural features of the gneiss are intimately related. Gneissose banding invariably parallels the margins of the intrusions and is deflected around inclusions of country rock, features implying that the basaltic and granitic components were injected into the peridotite in a plastic, commingled state. The gneiss intrusions located near the basal thrust typically exhibit a more continuous layered structure and a more penetrative mineral foliation, presumably a result of the transposition of net-veining and commingling textures during tectonism within the fault-zones. The observed spatial and volumetric relationships suggest that the granitic magma intruded a more voluminous body of basaltic magma as small diapirs. These initially chilled the surrounding mafic magma, resulting in fine-grained mafic enclaves and net-veined mafic bodies. These were subsequently deformed, and original textures transposed within low-angle thrust zones and high-angle normal faults.

In summary, its contact relationships with all other rock-types support an intrusive origin for the Kennack Gneiss, followed by tectonic transposition of primary features. The relationships between the mafic dykes and the gneiss are complex and suggest a dynamic, temporally overlapping intrusive history for the two, the granitic magmas utilizing preexisting conduits of the mafic component. The local presence of felsic stringers in the dykes, and the compatibility of mineral assemblages in the dykes and the mafic component of the gneiss, suggest that at least some of the former bodies may be genetically related to the latter.

\section{Implications of geochemistry}

The conclusions based on field relationships and petrographic observations are corroborated by the geochemical data. The ubiquitous negative linear covariance of the major and compatible trace elements with $\mathrm{SiO}_{2}$ in all felsic components is in conformity with magmatic mixing or, possibly, sourcecontrolled restite separation. Because the most silicapoor felsic rocks are characterized by the most peraluminous compositions, commonly have the highest HFSE and IREE contents, and are the most isotopically evolved, it is improbable that they record mixing with a mafic magma. The observed compositional variations are more consistent with restite separation from an intermediate crustal source (White \& Chappell 1977). The large ranges in Ta, Nb, Y and the heavy REE with only minor accompanying changes in $\mathrm{SiO}_{2}$ are typical of radical crystal-liquid fractionation. These observations imply that the overall distribution and variation of elements in the felsic component of the gneiss resulted from

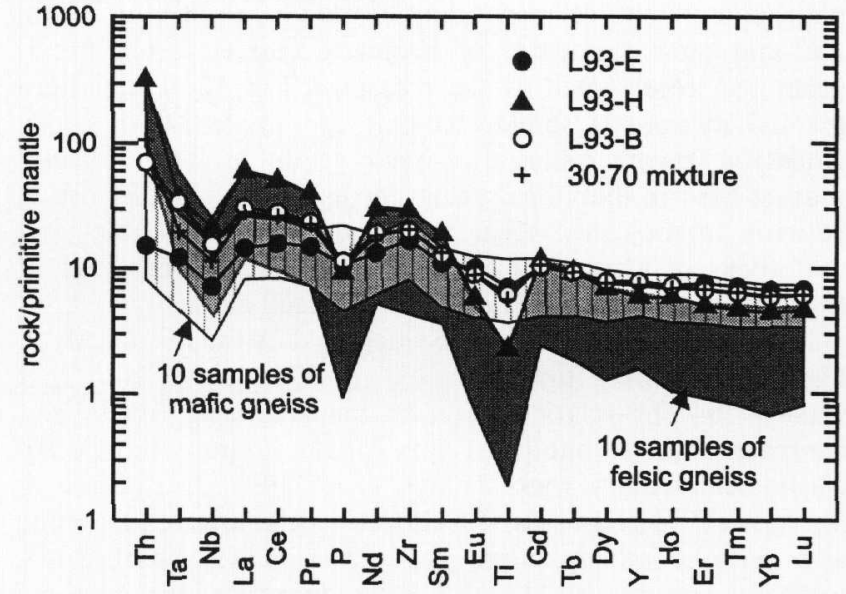

Fig. 12. Primitive mantle normalized (Sun \& McDonough 1989) extended trace element plot showing the fields defined by ten samples each of the mafic (vertical ruling) and felsic (dark shading) components of the Kennack Gneiss. Also shown are patterns for three samples from Kennack Sands. The solid circle pattern represents mafic component L93-E, the filled triangles $\mathrm{L} 93-\mathrm{H}$, and the open circles L93-B. A calculated mixture representing 30\% $\mathrm{L} 93-\mathrm{H}$ and $70 \% \mathrm{~L} 93-\mathrm{E}$ is also shown as crosses.

source-controlled restite separation, followed by fractionation and, finally, magmatic commingling. The mafic components as a whole, however, exhibit non-systematic trends for most major and compatible trace elements, a feature incompatible with simple fractionation of a basaltic assemblage of olivine+clinopyroxene+plagioclase. Rocks of mafic group 1 exhibit lower concentrations of the incompatible elements and are characterized by more primitive ${ }^{143} \mathrm{Nd} /{ }^{144} \mathrm{Nd}_{(t=376 \mathrm{Ma})}$ and ${ }^{87} \mathrm{Sr}^{86} \mathrm{Sr}_{(t=376 \mathrm{Ma})}$ values than those of group 2 . The latter commonly exhibit approximately linear covariation for most elements versus silica. Both the mafic and felsic components of the gneiss exhibit anomalous behaviour with respect to the middle and heavy REE and most other HFSE. These variations cannot be explained by models involving only simple partial melting, fractional crystallization or ideal mixing, but probably record all three.

\section{The role of magma mixing}

Barbarin \& Didier (1992) eloquently emphasize the possible complexities involved in the mechanical interpenetration of mafic and silicic magmas. They argue that magmatic commingling in spatially restricted, ephemeral, conduits will be dominated by mechanical exchange and that felsic-mafic magma mixing will occur on only a local scale, the degree and nature of hybridization probably varying markedly from conduit to conduit. Because the Kennack Gneiss comprises numerous areally restricted intrusive bodies, the compositional characteristics of both components would be expected to vary markedly and non-systematically from place to place, impeding any attempt to model the overall mixing relationships. Analysis of the mafic and felsic components of a single intrusion, however, may clarify the relationships. In Fig. 12, we plot primitive mantle-normalized (Sun \& McDonough 1989), extended trace element patterns for three specimens from the exposure at Kennack Sands, and model mixing using two of these, L93-H, felsic and L93-E, mafic (group 1), as end-members. Assuming $30 \%$ of the felsic and $70 \%$ of the 
mafic component, corresponding to the overall proportions in this and most exposures of Kennack Gneiss, a mixture is generated, represented by the crosses in Fig. 12. The pattern for the mixture is similar to that of sample L93-B (open circles), a basaltic andesite of mafic group 2a. This indicates that, at least in individual gneiss intrusions, magmatic mixing between mafic and silicic components is plausible and that rocks of mafic group 2 probably represent mixtures of fractionated felsic gneiss and group 1 mafic gneiss.

Mixing relationships are also elucidated by the isotopic data. Figure 11 shows time-corrected $(t=376 \mathrm{Ma}){ }^{143} \mathrm{Nd} /{ }^{144} \mathrm{Nd}$ versus ${ }^{87} \mathrm{Sr} /{ }^{86} \mathrm{Sr}$ relationships for the Kennack Gneiss and compares these to published data for the Gramscatho Group clastic sedimentary rocks (Floyd et al. 1991; Darbyshire \& Sheppard 1994). Samples of Kennack Gneiss are seen to define a hyperbolic mixing curve between a mantle source, isotopically comparable to the most primitive specimen of mafic Kennack Gneiss, and a Sr-enriched and Nd-depleted crustal source similar to the rocks of the Gramscatho Group. Figure 11 records a mixing curve in terms of ${ }^{143} \mathrm{Nd} /{ }^{144} \mathrm{Nd}$ and ${ }^{87} \mathrm{Sr} /{ }^{86} \mathrm{Sr}$ for a range of mixtures between the most primitive sample of mafic gneiss (L93-E: ${ }^{143} \mathrm{Nd}$ / ${ }^{144} \mathrm{Nd}_{t}=0.512495, \varepsilon_{\mathrm{Nd} t}=+6.7,{ }^{87} \mathrm{Sr}^{86} \mathrm{Sr}_{t}=0.702324, \varepsilon_{\mathrm{Sr} t}=-24.7$, $\mathrm{MgO}=8.55 \mathrm{wt} \%, \mathrm{Cr}=292 \mathrm{ppm}$ and $\mathrm{Ni}=120 \mathrm{ppm})$ and the most isotopically evolved specimen of the felsic gneiss (L93-H: ${ }^{143} \mathrm{Nd} /{ }^{144} \mathrm{Nd}_{t}=0.512002, \quad \varepsilon_{\mathrm{Nd} t}=-3.0, \quad{ }^{87} \mathrm{Sr}^{86} \mathrm{Sr}_{t}=0.704844$, $\varepsilon_{\mathrm{Sr} t}=+11.1$ ). Although the line does not uniquely model all of the data, the $30 \%$ L93-H+70\% L93-E mixture corresponds closely to sample L93-B, supporting our conclusion based on modelling of the trace element data.

\section{Magma sources}

Felsic component. The Kennack granitoids do not represent minimum melts, and are inferred to record a complex history involving derivation through source-controlled restite separation, probable crystal-liquid fractionation and finally magma mixing. This complex interplay of processes precludes the identification of the composition of a parental magma. However, because the most silica-poor granites are typically the most peraluminous $(\mathrm{A} / \mathrm{CNK}$ c. 1.25$)$ and have the lowest ${ }^{143} \mathrm{Nd} /{ }^{144} \mathrm{Nd}_{t}$ and highest ${ }^{87} \mathrm{Sr} /{ }^{86} \mathrm{Sr}_{t}$ isotopic compositions, it is probable that they most closely approach the composition of the primary magma, supporting a supracrustal, predominantly metasedimentary source (Chappell \& White 1974; White \& Chappell 1977). The decrease in heavy REE content with increasing silica suggests control by a phase such as garnet and/or zircon. Felsic rocks from the west coast appear to have lower light REE contents than most specimens from the east coast, possibly implying fractionation of a light-REE-bearing phase such as monazite. The field defined by all samples of the felsic component, and the pattern for sample $\mathrm{L93}-\mathrm{H}$ $\left(\mathrm{SiO}_{2}=69.7 \mathrm{wt} \%\right.$; $\mathrm{A} / \mathrm{CNK}=1.15$; Table 2$)$, are plotted in Fig. 12 , comparing the composition of the felsic components to primitive mantle (Sun \& McDonough 1989). The granites are characterized by negative $\mathrm{Ta}, \mathrm{Nb}, \mathrm{P}, \mathrm{Eu}$ and $\mathrm{Ti}$ anomalies of variable magnitudes. Eu anomalies imply the presence of plagioclase and/or alkali feldspar in the source and/or its fractionation from the magma. All of the observations suggest a crustal source with an intermediate composition, and containing plagioclase, alkali feldspar and, probably, quartz, as well as HFSE and heavy-REE-bearing accessory phases such as zircon and/or garnet.

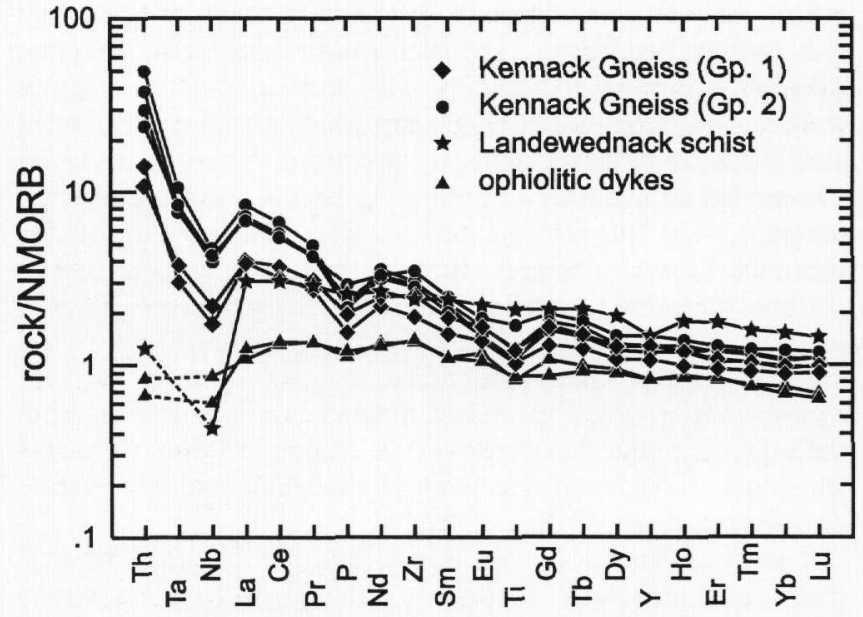

Fig. 13. N-MORB-normalized (Sun \& McDonough 1989) extended trace element plot for six samples of the mafic component of the Kennack Gneiss from Kennack Sands. Plotted for comparison are two samples from the Porthoustock dyke swarm (L7-19A \& L7-20A: Table 3) that are considered to constitute part of the ophiolite sequence and one specimen of Landewednack schist from Cadgwith (L7-67: Table 4).

The role of hydrous mineral phases in the generation of these rocks is more difficult to interpret. Their metaluminous to markedly peraluminous character indicates that dehydration melting of biotite and possibly muscovite may have significantly contributed to their formation (Clemens \& Vielzeuf 1987). Isotopic data strongly suggest that these granites were derived from a crustal source comparable to the sandstones and shales of the Gramscatho Group.

Mafic components. In Fig. 13, element abundances in six mafic samples from Kennack Sands (groups 1 \& 2), normalized to the N-MORB values of Sun \& McDonough (1989), are compared to the patterns for a specimen of Landewednack schist (L7-67: Fig. 2b) and two greenschist-facies dykes from the swarm near Porthoustock (Fig. 1). The gneiss samples yield patterns with gentle negative slopes, and with troughs at $\mathrm{Nb}$, $\mathrm{Ta}, \mathrm{P}$ and $\mathrm{Ti}$, such as characterize basaltic rocks in suprasubduction zone environments and/or that have undergone crustal contamination. Some of the samples also exhibit minor positive $\mathrm{Zr}$ anomalies. Taking into account these effects of differentiation and contamination, the abundance and overall shape of the extended trace element patterns suggest that the primary magma of the mafic components (group 1) was a tholeiitic partial melt of a weakly enriched mantle source, similar to EMORB. In contrast, the ophiolitic dykes of the Porthoustock swarm have generally flat patterns. The Landewednack schist is unlikely to be genetically related to the mafic Kennack Gneiss as it exhibits significantly lower Th and $\mathrm{Nb}$ and slightly higher abundances of the middle- and heavy REE, and is clearly enriched in those REE compared to the Porthoustock dykes. These observations imply that the chemistry of the mafic component of the Kennack Gneiss is incompatible with an ophiolitic origin.

\section{Implications for the tectonic history of $S W$ England}

The intrusion of the Kennack Gneiss along the base of, and into, the Goonhilly Downs unit, involving the emplacement of commingled, EMORB-like basaltic and crustally derived 
granitic melts, is now constrained to have occurred at $376.4 \pm 1.7 \mathrm{Ma}$. This new $\mathrm{U}-\mathrm{Pb}$ date is in permissive agreement with previous age determinations for the Kennack Gneiss, while the limited hiatus between it and published $\mathrm{Rb}-\mathrm{Sr}, \mathrm{K}-\mathrm{Ar}$ and ${ }^{40} \mathrm{Ar} /{ }^{39} \mathrm{Ar}$ ages implies that both amphibolite facies dynamothermal metamorphism at c. 10-14 km depth (Sandeman et al. 1995) and uplift and cooling immediately followed, or even overlapped with, intrusion.

The felsic component of the Kennack Gneiss has geochemical and isotopic characteristics compatible with derivation through anatexis of immature sedimentary rocks comparable to the Gramscatho Group. This is compelling evidence that the assembled ophiolite overlay the flysch sequences of SW England at that time, thereby providing the first direct evidence for the timing of continental incorporation of the Lizard Complex. The EMORB-like character of the mafic component of the Kennack Gneiss is distinct from the NMORB compositions of the Lizard ophiolite proper, and is compatible with generation in an off-spreading axis environment, possibly marginal to a mantle plume.

A prerequisite for clarification of the geodynamic significance of the Lizard Complex is the delimitation of tectonothermal events during the c. $21 \mathrm{Ma}$ hiatus between the generation of the oceanic lithosphere (at $\geq 397 \pm 2$ Ma: Clark et al. 1998a) and its emplacement onto the SE Avalonian margin, a task beyond the scope of this investigation. We document, however, a change from early MORB-like magmatic activity at an oceanic spreading centre to final bimodal volcanism involving EMORB-like mafic, and crustally derived felsic magmatism at c. $376 \mathrm{Ma}$. This time-composition sequence is compatible with magmatism generated in association with formation and closure of a Devonian 'Rhenohercynian' ocean (see Pin 1990) and is in overall agreement with the model of Holder \& Leveridge (1986).

We are indebted to the technical and analytical staff of the Department of Earth Sciences at Memorial University of Newfoundland and of the Geochemical Laboratories of the Geological Survey of Canada for their laboratory and logistical support. This research was initiated as part of an MSc thesis by the first author at Memorial University of Newfoundland, for which funding was provided through a Provincial Government of Newfoundland Graduate Scholarship, and by Natural Sciences and Engineering Research Council (NSERC) operating grants to A.H.C. and J.G.M. M.T. Styles of the British Geological Survey is warmly thanked for providing access to the IGS drillcore and for many stimulating conversations about the Kennack Gneiss. R. Thériault and $\mathrm{K}$. Tomlinson are thanked for reviews of earlier versions of this manuscript. M. Henderson and an anonymous reviewer substantially improved the manuscript. This is the Geological Survey of Canada contribution 1999067.

\section{References}

BACON C.R. 1986. Magmatic inclusions in silicic and intermediate volcanic rocks. Journal of Geophysical Research, 91, 6091-6112.

Barbarin, B. 1988. Field evidence for successive mixing and mingling between the Piolard Diorite and the Saint-Julien-la-Vetre Monzogranite (NordForez, Massif Central, France). Canadian Journal of Earth Sciences, 25, $49-59$.

_ \& Didier J. 1992. Genesis and evolution of mafic microgranular enclaves through various types of interaction between coexisting felsic and mafic magmas. Transactions of the Royal Society of Edinburgh, 83, 145-153.

Barker, F. 1979. Trondhjemites, Dacites and Related Rocks. Developments in Petrology No. 6, Elsevier Scientific Publishing Company, Amsterdam.

BARNES, R.P. \& ANDREWS J.R. 1984. Hot or cold emplacement of the Lizard Complex? Journal of the Geological Society, London, 141, 37-39.
_-_ \& 1986. Upper Palaeozoic ophiolite generation and obduction in south Cornwall. Journal of the Geological Socieiy, London, 143, 117-125.

BonNEx, T.G. 1896. The serpentine, gneissoid, and hornblende rocks of the Lizard District. Quarterly Journal of the Geological Society of London, 52, $17-51$.

Bromley, A.V. 1979. Ophiolitic origin of the Lizard Complex. Journal of Camborne School of Mines, 29, 25-38.

Chappell, B.W. \& White A.J.R. 1974. Two contrasting granite types. Pacific Geology, 8, 173-174

Cl.ark, A.H., Sandeman H.A., Lui C., Scott D.J., Farrar E., Archibald D.A., Bromley A.V., Jones K.A. \& W ARR L.N. 1998b. An emerging geochronological record of the construction and emplacement of the Lizard ophiolite, SW Cornwall (Extended Abstract). Geoscience in South-West England, 9, 276-277.

—, Scott, D.J., Sandemay, H.A., Bromley, A.V. \& - 1998a. Siegenian generation of the Lizard ophiolite: U-Pb zircon age data for plagiogranite, Porthkerris, Cornwall. Journal of the Geological Society, London, 155, 595-598.

Ciemens, J.D. \& Vielzeuf D. 1987. Constraints on melting and magma production in the crust. Earth and Planetary Science Letters, 86, 287--306.

DARBYSHIRE, D.P.F. \& SHEPHERD T.J. 1994. Nd and Sr isotope constraints on the origin of the Cornubian batholith, SW England. Journal of the Geological Society, London, 151, 795-802.

Davies. G.R. 1984. Isotopic evolution of the Lizard Complex. Joumal of the Geological Society: London, 141, 3-14.

De LA BeCHE, H.T. 1839. One inch geological map 32 (Old Series), Lizard Head, Geological Survey of Great Britain.

DEPAOLO, D.J. 1981. Neodymium isotopes in the Colorado Front Range and crust-mantle evolution in the Proterozoic. Nature, 291, 193-196.

_._-_ Wasserburg G.J. 1976. Nd isotopic variations and petrogenetic models. Geophysical Research Letters, 3. 249-252.

Donson, M.H. 1961. Isotopic ages from the Lizard peninsula, South Cornwall. Proceedings of the Geological Society of London, 1591, 133-136.

FIETT, J.S. 1946. Geology of the Lizard and Meneage. Memoirs of the Geological Survey of Great Britain (second edition). H.M.S.O., London.

FLOYD, P.A.. EXLEY C.S. \& STYLES M.T. 1993. Igneous rocks of southwest England. In: Wimbledon W.A. \& Banham P.H. (eds) Igneous rocks of soutwest England. Geological Conservation Review Series, 5. Chapman and Hall, London.

--, Shail, R., Leveridge, B.E. \& Franke W. 1991. Geochemistry and provenance of Rhenohercynian synorogenic sandstones: implications for tectonic environment discrimination. In: MORTON A.C., TODD S.P. \& Haughton P.D.W. (eds) Developments in Sedimentary Provenance Studies. Geological Society, London, Special Publications, 57, 173-188.

Frost, T.P. \& MAHOOD G.A. 1987. Field, chemical, and physical constraints on mafic-felsic magma interaction in the Lamarck Granodiorite, Sierra Nevada, California. Geological Society of America Bulletin, 99, 272-291.

GibBons, W. \& Thompson L. 1991. Ophiolitic mylonites in the Lizard complex: ductile extension in the lower oceanic crust. Geology, 19, 1009-1012.

GreEn, D.H. 1964a. The petrogenesis of the high-temperature peridotite in the Lizard area, Cornwall. Journal of Petrology, 5, 134-188.

- 1964b. A re-study and re-interpretation of the geology of the Lizard Peninsula, Cornwall. In. Hosking K.F.G. \& Shrimptov G.J. (eds) Present Views on Some Aspects of the Geology of Cornwall and Devon. Royal Geological Society of Cornwall, 87-114.

Holder, M.T. \& LeVeridge B.E. 1986. A model for the tectonic evolution of south Cornwall. Journal of the Geological Society, London, 143, 125-135.

IRvine, T.N. \& BarAGER W.R.A. 1971. A guide to the chemical classification of the common volcanic rocks. Canadian Joumal of Earth Sciences, 8, 523-548.

KIRBY. G. A. 1979a. The Petrochemistry of Rocks of the Lizard Complex, Cornwall. $\mathrm{PhD}$ thesis, Southampton University. 1979h. The Lizard Complex as an ophiolite. Nature, 282, 58-60.

- 1984. The petrology and geochemistry of dykes of the Lizard Ophiolite Complex, Cornwall. Journal of the Geological Society, London, 141, $53-59$.

LFake, R.C. \& Styles M.T. 1984. Borehole sections through the Traboe hornblende schists, a cummulate complex overlying the Lizard peridotite. Journal of the Geological Society, London, 141, 41-52.

Leveridge, B.E., Holder M.T. \& Goode A.J.J. 1990. Geology of the Country around Falmouth. Memoir for 1:50000 Geological Sheet 352 (England \& Wales),

MaLPas, J.G. \& LANGdon G.S. 1987. The Kennack Gneisses of the Lizard Complex, Cornwall, England: partial melts produced during ophiolite emplacement. Canadian Journal of Earth Sciences, 24, 1966-1974. 
Middelburg, J.J., Van Der Weijden C.H. \& Wolttiez J.R.W. 1988. Chemical processes affecting the mobility of major, minor and trace elements during weathering of granitic rocks. Chemical Geology, 68, 253 273.

Miller, J.A. \& Green D.H. 1961. Age determinations of rocks in the Lizard (Cornwall) area. Nature, 192, 1175-1176.

Miyashiro, A. 1974. Volcanic rock series in island ares and active continental margins. American Journal of Science, 274, 321-355

Pearce, J.A. \& CANN J.R. 1973. Tectonic setting of basic volcanic rocks determined using trace element analyses. Earth and Planetary Science Letters. 19, 290-300.

PIN, C. 1990. Variscan oceans: ages, origins and geodynamic implications inferred from geochemical and radiometric data. Tectonophysics, 177, 215-227.

Sandeman, H.A., Chin Y., Clark A.H. \& Farrar E. 1995. Constraints on the P-T conditions and age of emplacement of the Lizard ophiolite, Cornwall: amphibole-plagioclase thermobarometry and ${ }^{40} \mathrm{Ar} /{ }^{39} \mathrm{Ar}$ geochronology of basal amphibolites. Canadian Journal of Earth Sciences, 32, 261-272.

—, Clark, A.H., Styles, M.T., Scott, D.J., Malpas J.G. \& Farrar E. 1997. Geochemistry and $\mathrm{U}-\mathrm{Pb}$ and ${ }^{40} \mathrm{Ar}-{ }^{39} \mathrm{Ar}$ geochronology of the Man of War Gneiss, Lizard Complex, SW England: pre-Hercynian arc-type crust with a Sudeten-Iberian connection. Journal of the Geological Society, London, 145. 403-417.

- Relf, C. \& Maclachlan, K. 1999. Preliminary geochemical and $\mathrm{Nd}$ isotopic investigations of Archean volcanic and volcaniclastic rocks of the Yathkyed greenstone belt, Kivalliq region. Northwest Territories. Radiogenic Age and Isotopic Studies Report 12, Geological Survey of Canada Current Research Paper 1999-F.

SANDERs, L.D. 1955. Structural observations on the southeast Lizard, Geological Magazine, 92, 231-240.

Sparks, R.S.J. \& Marshall L.A. 1986. Thermal and mechanical constraints on mixing between mafic and silicic magmas. Journal of Volcanology and Geothermal Research, 29, 99-124.

STACFY, J.S. \& Kramers J.D. 1975. Approximation of terrestrial lead isotope evolution by a two-stage model. Earth and Planetary Science Letters, 26. 207-221.

StEIGER, R.H. \& JäGER E. 1977. Subcommission on geochronology: convention on the use of decay constants in geo- and cosmochronology. Earth and Planetary Science Letters, 36, 359-362.
Strong, D.F., Stevens R.K., Malpas J.G. \& Badham J.P.N. 1975. A new tale for the Lizard. Proceedings of the Ussher Society, 3, 252-265.

STYLES, M.T. \& Kirby G.A. 1980. New investigations of the Lizard Complex, Cornwall, England, and a discussion of an ophiolite model. In. Panaylotou A. (ed.) Proceedings of the International Ophiolite Symposium Nicosia. Cyprus, 1979. Geological Survey Department Nicosia, Cyprus $517-526$.

- _ \& RundLE, C.C. 1984. The Rb-Sr isochron age of the Kennack Gneiss and its bearing on the age of the Lizard Complex, Cornwall. Journal of the Geological Society, London, 141, 15-19.

Sun, S.S. \& MCDONovgh W.F. 1989. Chemical and isotopic systematics of oceanic basalts: implications for mantle composition and processes. In. SAunders A.D. \& NoRRY M.J. (eds) Magmatism in the Ocean Basins. Geological Society London Special Publications 42, 313-345.

TeAll, J.J.H. 1887. On the origin of certain banded gneisses. Geological Magazine, 4, 484-493.

Thayer, T.P. 1969. Peridotite-gabbro complexes as keys to petrology of mid-ocean ridges. Geological Society of America Bulletin, 80, 1515-1522.

THÉRIAULT, R.J. 1990. Methods for Rb-Sr and Sm-Nd isotopic analyses at the geochronology laboratory. Geological Survey of Canada. Radiogenic Age and Isotopic Studies Report 3, Geological Survey of Canada Current Research Paper 89-2

Vernov, R.H.. ETheridge M.A.\& WALl V.J. 1988. Shape and microstructure of microgranitoid enclaves: indicators of magma mingling and flow. Lithos, 22, $1-1$ l.

White, A.J.R. \& Chappell B.W. 1977. Ultrametamorphism and granitoid genesis. Tectonophysics, 43, 7-22.

Winchester, J.A. \& FloYd P.A. 1977. Geochemical discrimination of different magma series and their differentiation products using immobile elements. Chemical Geology, 20, 325-343.

Wood, D.A., JoRon J.L. \& TreulL M. 1979. A re-appraisal of the use of trace elements to classify and discriminate between magma series erupted in different tectonic settings. Earth and Planetary Science Letters, 50, 326-336.

YORK, D. 1969. Least squares fitting of a straight line with correlated errors. Earth and Planetary Science Letters, 5, 320-324. 